\title{
Quality-Assurance and Data Management Plan for Ground water Activities by the U.S. Geological Survey in Kansas, 2014
}

Open-File Report 2014-1060 



\section{Quality-Assurance and Data Management Plan for Groundwater Activities by the U.S. Geological Survey in Kansas, 2014}

By James E. Putnam and Cristi V. Hansen

Open-File Report 2014-1060 


\title{
U.S. Department of the Interior SALLY JEWELL, Secretary
}

\section{U.S. Geological Survey Suzette M. Kimball, Acting Director}

\author{
U.S. Geological Survey, Reston, Virginia: 2014
}

For more information on the USGS - the Federal source for science about the Earth, its natural and living resources, natural hazards, and the environment, visit http://www.usgs.gov or call 1-888-ASK-USGS.

For an overview of USGS information products, including maps, imagery, and publications, visit http://www.usgs.gov/pubprod

To order this and other USGS information products, visit http://store.usgs.gov

Any use of trade, firm, or product names is for descriptive purposes only and does not imply endorsement by the U.S. Government.

Although this information product, for the most part, is in the public domain, it also may contain copyrighted materials as noted in the text. Permission to reproduce copyrighted items must be secured from the copyright owner.

Suggested citation:

Putnam, J.E., and Hansen, C.V., 2014, Quality-assurance and data management plan for groundwater activities by the U.S. Geological Survey in Kansas, 2014: U.S. Geological Survey Open-File Report 2014-1060, 37 p., http://dx.doi. org/10.3133/ofr20141060.

ISSN 2331-1258 (online 


\section{Contents}

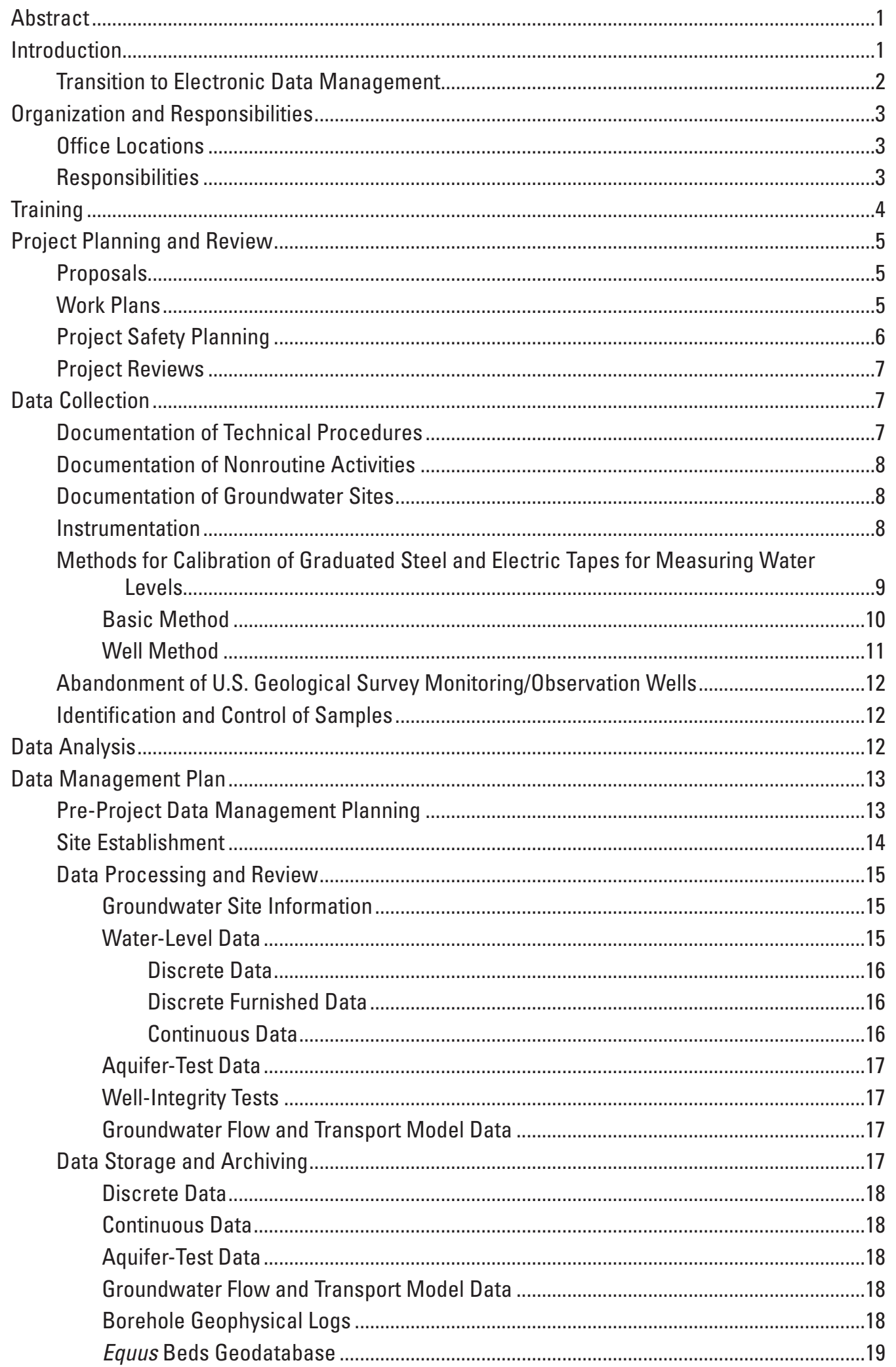




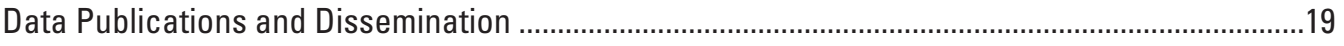

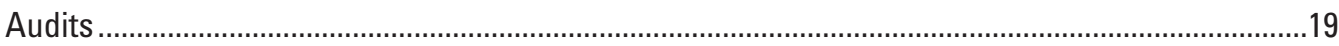

Summary.

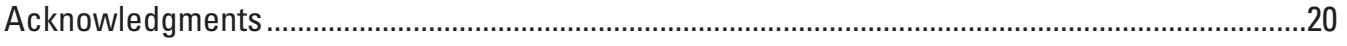

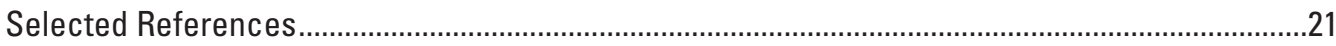

Appendix 1-Establishment of Site Files for New Groundwater Data-Collection Sites .................24

Conducting a Search for Duplic ate Data-Collection Sites ....................................................24

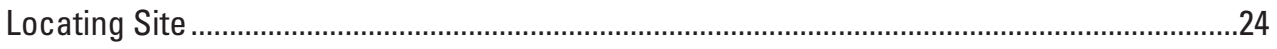

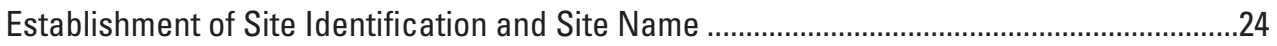

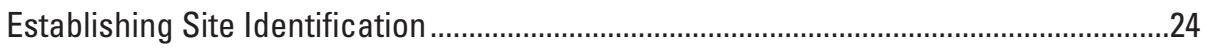

Groundwater (well, spring) .............................................................................24

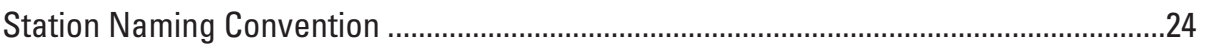

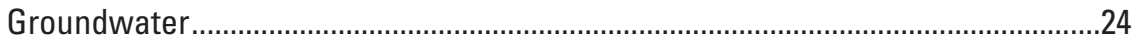

Groundwater Site Inventory (GWSI) Site Schedules.........................................................25

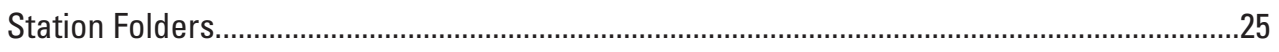

Appendix 2-Establishment of Real-Time Web Sites ..............................................................2

Additional Groundwater Site Inventory Requirements for Real-Time Display .........................27

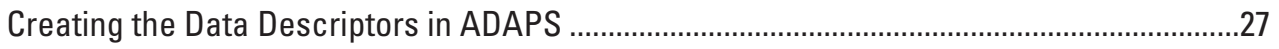

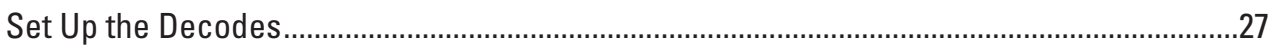

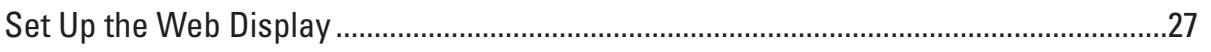

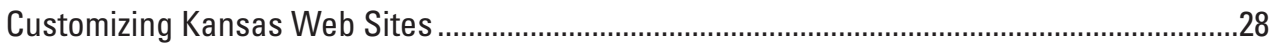

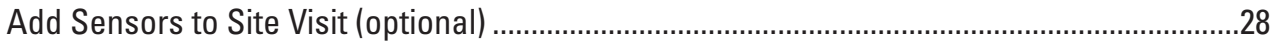

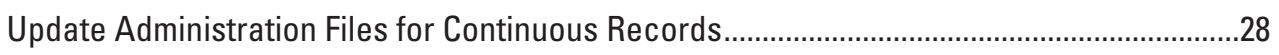

Appendix 3 -Groundwater Technical Memorandum 2012.01....................................................29

Appendix 4-Distribution of USGS Information Prior to Publication .................................................34

\section{Figures}

1-1. Diagram showing modified Bureau of Reclamation system of land subdivision used for

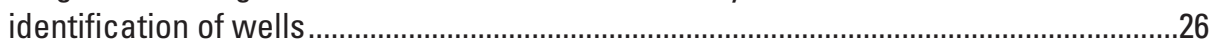

\section{Tables}

1. Example of a calibration record for steel tape or electric tape.

2. Report review process for quality assurance in the U.S. Geological Survey Kansas Water Science Center 


\section{Abbreviations}

\begin{tabular}{|c|c|}
\hline ADAPS & Automated Data Processing System \\
\hline ASTM & American Society of Testing and Materials \\
\hline CBR & collection of basic records \\
\hline DBA & database administrator \\
\hline DCP & data-collection platform \\
\hline DD & data descriptor \\
\hline DMP & data management plan \\
\hline FSP & fundamental science practices \\
\hline GWPD & groundwater procedure documents \\
\hline GWOAP & groundwater quality-assurance plan \\
\hline GWSI & Groundwater Site Inventory \\
\hline JHA & job hazard analysis \\
\hline KDHE & Kansas Department of Health and Environment \\
\hline KGS & Kansas Geological Survey \\
\hline KSWSC & Kansas Water Science Center \\
\hline MAPS & Management and Population of Sites Application \\
\hline NWIS & National Water Information System \\
\hline NWQL & National Water Quality Laboratory \\
\hline OGW & Office of Groundwater \\
\hline OMB & Office of Management and Budget \\
\hline QWDATA & quality of water data \\
\hline RMS & Records Management System \\
\hline SIMS & Site Information Management System \\
\hline SPN & Science publishing network \\
\hline SWAMI & Surface-water Measurement and Inspection \\
\hline SWUDS & Site-Specific Water-Use Data System \\
\hline USGS & United States Geological Survey \\
\hline WIMAS & Water Information Management and Analysis System \\
\hline WIZARD & Water Information Storage and Retrieval Database \\
\hline WMA & Water Mission Area \\
\hline WRD & Water Resources Division \\
\hline WSFT & Water Science Field Team \\
\hline WWC & water-well completion \\
\hline
\end{tabular}





\title{
Quality-Assurance and Data Management Plan for Groundwater Activities by the U.S. Geological Survey in Kansas, 2014
}

\author{
By James E. Putnam and Cristi V. Hansen
}

\section{Abstract}

As the Nation's principle earth-science information agency, the U.S. Geological Survey (USGS) is depended on to collect data of the highest quality. This document is a qualityassurance plan for groundwater activities (GWQAP) of the Kansas Water Science Center. The purpose of this GWQAP is to establish a minimum set of guidelines and practices to be used by the Kansas Water Science Center to ensure quality in groundwater activities. Included within these practices are the assignment of responsibilities for implementing qualityassurance activities in the Kansas Water Science Center and establishment of review procedures needed to ensure the technical quality and reliability of the groundwater products. In addition, this GWQAP is intended to complement qualityassurance plans for surface-water and water-quality activities and similar plans for the Kansas Water Science Center and general project activities throughout the USGS.

This document provides the framework for collecting, analyzing, and reporting groundwater data that are quality assured and quality controlled. This GWQAP presents policies directing the collection, processing, analysis, storage, review, and publication of groundwater data. In addition, policies related to organizational responsibilities, training, project planning, and safety are presented. These policies and practices pertain to all groundwater activities conducted by the Kansas Water Science Center, including data-collection programs, interpretive and research projects. This report also includes the data management plan that describes the progression of data management from data collection to archiving and publication.

\section{Introduction}

The U.S. Geological Survey (USGS) is involved in a wide variety of groundwater data-collection programs and investigations to assess the status of the Nation's groundwater resources. Results of these activities are used to aid the Nation in developing, managing, and maintaining its groundwater resources. As the Nation's principal earth-science information agency, the USGS is depended on to collect accurate data and produce factual and impartial interpretive reports. Methods for data collection and analysis that were developed by the USGS have become standard techniques used by numerous Federal, State, and local agencies and by private enterprises. Data collected by scientific organizations such as the USGS are being used increasingly by the public to define and examine a variety of natural-resource and environmental problems (Brunett and others, 1997). Many of these problems are addressed through an open, public process. As a result, scientific organizations are being challenged to demonstrate the credibility of their data on the basis of objective evidence rather than on the organization's history and reputation.

The purpose of the USGS Kansas Water Science Center (KSWSC) groundwater quality-assurance plan (GWQAP) is to document policies and procedures for documentation and review of groundwater activities (data collection and interpretive studies) conducted by the KSWSC. This quality-assurance plan was prepared as required by the Office of Groundwater (1997a) because the goal of quality assurance is to provide high-quality data, and the availability of high-quality data is the foundation of any groundwater analysis (Alley and others, 1999). Adherence to the quality-assurance plan will assist personnel in ensuring the technical quality and reliability of the groundwater data and products of the KSWSC. The KSWSC GWQAP is intended to be a living document that is updated regularly as policy, procedures, and technology change. The staff of the KSWSC, particularly those directly involved in the collection, processing, and analysis of groundwater data, is encouraged to make suggestions for improvement of the KSWSC GWQAP. Suggestion for improvement of the GWQAP will be directed to the KSWSC Director, Data or Hydrologic Investigations Section Chiefs, and Groundwater Specialist.

The KSWSC GWQAP is based on the following principles:

1. USGS groundwater programs and projects in Kansas will be planned efficiently and effectively to provide information needed to evaluate local, State, and national water problems.

2. Technical and scientific activities will be performed in accordance with applicable USGS practices and policies. 
3. Groundwater activities will be performed by technically qualified personnel performing at a level commensurate with their training and experience.

4. All such activities and projects will receive appropriate and timely review for completeness, reliability, and credibility.

5. Remedial actions will be taken to correct any observed technical or project deficiency.

6. Implementation of the GWQAP will enhance groundwater data collected by the KSWSC by providing for the following:

- Consistency (across projects and offices);

- Comparability (produce results of known quality);

- Repeatability (documentation of techniques that consistently lead to similar results with the same accuracy);

- Accountability (to customers, the scientific community, and regulatory agencies); and

- Traceability (written record of how and when work was done, who did the work, and when work was performed, personnel training, equipment used, and so forth).

The intent of the KSWSC GWQAP does not differ in any substantial way from similar plans addressing water-quality and surface-water activities. Groundwater, surface water, and water quality are three components of a dynamic, complex, interrelated system. To ensure uniformity, consistency, and repeatability for groundwater, surface-water, and water-quality activities, it is important to develop and integrate standard field, laboratory, and office procedures and protocols in all three areas. The purpose of this GWQAP is to establish a minimum set of guidelines and practices to be used by the KSWSC to ensure quality in groundwater activities. The GWQAP is intended to complement quality-assurance plans for surfacewater and water-quality activities and similar plans for the KSWSC and general project activities throughout the USGS. Included within these practices are the assignment of responsibilities for implementing quality-assurance activities in the KSWSC and establishment of review procedures needed to ensure the technical quality and reliability of the groundwater products.

Policies and practices pertaining to organizational responsibilities; project planning and management; training; safety; data collection, processing, review, storage, and analysis; and publication of groundwater data are addressed in the GWQAP. The policies and practices pertain to all groundwater activities conducted by or for the KSWSC. Groundwater activities include tasks pertaining to data-collection programs, interpretive and research projects, and data management.

Because of the great emphasis on data synthesis and interpretation in groundwater studies, and because of the limited number of formal standards to govern the conduct of such studies, the GWQAP places great emphasis on the technical review process. For example, there is no single established technique used to select "correct" values of storage coefficient or transmissivity for use in a groundwater flow model or other publication. The formal training, breadth of experience, and technical judgment of the Project Chief, the Section Chief, the KSWSC Director, and the KSWSC Groundwater Specialist contribute to ensuring the quality and integrity of groundwater data and, therefore, the interpretive reports incorporating these data.

Procedures for quality assurance in this GWQAP generally conform to guidelines presented in Brunett and others (1997). Groundwater procedure documents (GWPD) are summarized in Cunningham and Schalk (2011).

This report also includes the KSWSC data management plan (DMP). The management and archival of project data are part of the USGS mission and an important part of proper project management. The KSWSC DMP provides policy and procedures used by the KSWSC staff regarding management of data and records collected for hydrologic investigations. The DMP provides policy and procedures for the storage, documentation, publication, and archiving of data and records generated by the KSWSC. It is the responsibility of all KSWSC staff that collects or compiles hydrologic data to follow the procedures provided in this report. It is the policy of the KSWSC that data collected to meet the objectives of the KSWSC programs be documented, organized, and archived in a manner that (1) facilitates retrieval, evaluation, and use by KSWSC personnel and others and (2) enables an independent verification of data contained in reports and computer databases.

\section{Transition to Electronic Data Management}

The KSWSC began transitioning to electronic data management of all hydrologic data and records October 2013, corresponding with the beginning of the Federal fiscal and water year 2014. Before that, data were stored in either paper or electronic format. The primary changes in KSWSC data management are related to data-collection records and project records, most of which were being stored in paper format. The ultimate goal is to move to a "paperless" system where all data are collected electronically and stored in digital format. While the KSWSC transitions to electronic data storage, existing project files will be migrated into the centrally located electronic KSWSC directory. New projects will store all data and files in the electronic directory from the onset of the project. To facilitate the goal of complete electronic data storage, paper records will be digitally scanned and stored in the KSWSC directory as the original form. When additional practical datastorage capabilities are available in national databases and applications, the KSWSC will use those resources for appropriate data storage and archiving.

Various computer directories where groundwater information may be stored are mentioned throughout this report. 
As the transition to complete electronic data management progresses, these locations may change as the process is developed more fully.

\section{Organization and Responsibilities}

Quality assurance is an active process. Achieving and maintaining high-quality standards for groundwater data are accomplished by following established protocols. Failure to adhere to established protocols may result in errors and deficiencies in groundwater data and interpretation of those data. Clear and specific statements of responsibilities promote an understanding of each person's duties in the overall process of ensuring quality groundwater data.

\section{Office Locations}

The KSWSC has offices throughout Kansas that collect groundwater data and conduct groundwater studies. Groundwater hydrologic investigations are conducted out of the main office in Lawrence. Field offices are located in Lawrence, Hays, and Wichita. The KSWSC organizational structure is similar to those of other States in the USGS.

\section{Responsibilities}

The Director ultimately is responsible for groundwater quality assurance in the KSWSC; however, by delegation directly or indirectly, the Director shares certain aspects of quality assurance with the Chiefs of the Data and Hydrologic Investigations Sections, the Field Office Chiefs, the Groundwater Specialist, and Project Chiefs. These individuals share their responsibilities with those who collect, store, interpret, or disseminate groundwater data and interpretations. The following sections list the general responsibilities of the KSWSC personnel involved with or supervising groundwater activities. Moreover, more specific responsibilities are identified throughout the GWQAP.

The following is a list of general responsibilities of USGS personnel involved with groundwater data in Kansas. Specific responsibilities are identified later within the text.

The Kansas WSC Director is responsible for the following:

- Managing and directing the KSWSC program in Kansas, including all groundwater activities.

- Ensuring that groundwater activities in the KSWSC meet the needs of cooperating agencies, including State and local agencies, the general public, and the Federal government.

- Ensuring that all aspects of this GWQAP and DMP are understood and followed by KSWSC personnel.
- Providing final resolution of any conflicts or disputes related to groundwater activities within the KSWSC.

- Keeping KSWSC staff in Kansas briefed on procedural and technical communications from Region and Headquarters.

- Ensuring that technical reviews of all groundwater activities are conducted.

- Ensuring that all publications and other technical communications released by the KSWSC are accurate and are in accord with USGS policy.

- Ensuring that groundwater training is incorporated into each employee's training plan, where appropriate.

The Studies Section Chief is responsible for the following:

- Managing and directing groundwater activities assigned to the Studies section and ensuring that the stated objectives are met in a timely manner.

- Reviewing the work plans for groundwater programs and projects.

- Providing the Project Chiefs with technical and administrative support as needed.

- Creating, with groundwater personnel in the section, a training plan for each employee, when appropriate.

- Reviewing groundwater reports under his or her direction.

- Ensuring that all continuous and discrete data are reviewed and approved.

- Monitoring progress of groundwater Project Chiefs in implementing the groundwater quality-assurance and data management plans for their respective projects.

- Ensuring that procedures and policies of the GWQAP and DMP are implemented by their section.

- Developing scientific water resources programs.

The Project Chief is responsible for the following items:

- Directing and conducting the technical work of the project, including all phases of data collection, data review and approval data storage, data analysis, and report preparation according to appropriate procedures.

- Communicating project plans, progress, and problems to supervisors by providing written progress reports at periodic reviews.

- Preparing written work plans, documenting project activities, and ensuring that data are placed in the USGS National Water Information System (NWIS) or Groundwater Site Inventory (GWSI) databases, as appropriate, prior to project termination. 
- Maintaining a project file (paper or digital) containing memoranda, personal communications, technical-procedure documents used, original data, and other project documentation.

- Ensuring that project activities are carried out in a timely manner.

- Archiving of project files, including any aquifer test, groundwater models, surface or borehole geophysical logs, at the completion of the project.

- Ensuring that all continuous data are reviewed and that all discrete data collected are approved.

- Developing scientific program in their area of expertise.

The KSWSC Groundwater Specialist is responsible for the following items:

- Maintaining current groundwater technical expertise for the KSWSC.

- Consulting with the KSWSC staff on groundwater technical matters.

- Advising on training needs for employees engaged in groundwater activities.

- Participating in technical reviews of groundwater activities.

- Reviewing groundwater-related project proposals.

- Reviewing groundwater-related project reports.

- Ensuring that Project Chiefs have reviewed and approved all continuous and discrete data.

- Assisting Section Chief and Project Chiefs in program development.

Project and Field Staff are responsible for the following:

- Applying policies and guidelines of the GWQAP and DMP to groundwater data-collection and analysis activities to include continuous data processing, review, and approval of discrete data.

- Following established groundwater technical procedures for groundwater data collection and analysis.

- Documenting data-collection and data-analysis activities.

- Seeking technical guidance from the Project Chief, Section Chief, and Groundwater Specialist, as needed.

- Participating in development of personal training plans.

The Database Administrator (DBA) is responsible for the following:

- Maintaining data integrity within the NWIS database.
- Performing, or assigning to appropriately trained personnel, the entry, checking, updating, and retrieval of all data entered into the database according to USGS and WSC policies and procedures.

- Informing and discussing with the Project Chief, discipline specialist, and (or) Section Chief about any data conflicting with USGS or WSC policies or procedures.

- Maintaining familiarity with database updates and performing periodic database maintenance checks and updates.

- Training appropriate personnel in data checking, entry, updating, and retrieval from the database.

- Informing Section Chiefs of the training needs of personnel for the databases.

- Assisting the discipline specialists with updating and revising the GWQAP, DMP, and policies and procedures of the WSC.

The Computer Section is responsible for the following:

- Directing and participating as necessary in upgrades to the NWIS databases.

- Installing reference lists.

- Installing and managing the database instance (environment).

- Maintaining the local area computer network along with remote access.

- Maintaining and interfacing new and existing hardware.

- Installing and revising software needed to interface with NWIS.

- Ensuring the checkpoint, backup, and optimization of NWIS databases and, if necessary, their recovery.

- Performing appropriate data backup procedures in a timely manner.

- In coordination with the Section Chief and the DBA(s), determining and setting access rights of personnel for the databases.

- Making technical information for upgrades to the databases available to all personnel.

\section{Training}

The qualifications of project personnel relative to the technical demands of the work will be determined by the Project Chief, Section Chief, and WSC Discipline Specialists. 
Training will be used to ensure technical competence or to rectify inadequacies. Individuals will receive appropriate training before assigned tasks are performed. Appropriate training includes new employee orientation training, USGS National Training Center courses, online training, mentoring, on-the-job training, vendor-provided training, and academic courses.

Training will be provided routinely to field personnel by appropriate USGS or outside specialists, as necessary, to ensure uniformity in data-collection practices. For example, the Project Chief will require that water-level data for an observation well be plotted on a hydrograph of previous measurements as a check for gross errors. In those activities that involve the use of instrumentation (pressure transducers, data loggers, flow meters, geophysical equipment, and so forth), training of field personnel by qualified individual(s) will be conducted as necessary. Field personnel will be provided with and will be expected to be familiar with the manufacturers' manuals (or equivalent substitute) on all instrumentation. These manuals are maintained by the person using or responsible for maintaining the instruments. The WSC Discipline Specialists will ensure that proper training is being provided for ongoing and planned activities. The WSC Groundwater Specialist will ensure, when applicable, that suitable cross training in water-quality procedures is provided. If, while supervising field activities, the Project Chief notes training deficiencies, he or she will notify the Section Chief, who will ensure that proper training is arranged.

The supervisor and employee develop a training plan with some input from the WSC training officer. The plan is reviewed and updated at least annually as part of the performance review process. Each training activity is documented in the WSC training files that are maintained by the WSC Training Officer. Groundwater technical procedures of the U.S. Geological Survey" is provided to cooperators who provide furnished groundwater data to the KSWSC (Cunningham and Shalk, 2011).

\section{Project Planning and Review}

Project planning (Green, 1991), which includes the documentation of individual project tasks, quality objectives, and project deadlines, is necessary to increase the probability of successful project outcomes. Initial project/program planning is guided by a detailed work plan, and continued planning is guided by periodic technical project reviews.

Quality-assurance requirements will be integrated into the project proposal if one is required for the groundwater activity. Whether a groundwater program or project requires a separate quality-assurance plan will be evaluated on the basis of the complexity of the work, the needs of the WSC or cooperator, or other criteria as described by Shampine and others (1992).

\section{Proposals}

Project planning begins during proposal development when the proposal writer considers various approaches to meet the customer's needs and develops a project schedule that concurs with proposed funding. A proposal will be prepared for all reimbursable, Cooperative Water Program, and Other Federal Agency water-resources interpretive and some data projects [see Water Mission Area (WMA) Memorandum 13.01 for more details, U.S. Geological Survey, 2013a]. All projects that require a proposal should have an approved proposal before work begins.

Prior to initiating the formal proposal process, the proposal writer is encouraged to informally discuss proposed water-resources project concepts with appropriate Water Science Field Team (WSFT) technical (groundwater, waterquality, and surface-water) specialists, WSFT Chief, Regional Science Advisor, and Regional Safety Officer. Although not required, it is recommended that pre-proposals be submitted for review by the WSFT technical specialists. The WSFT review of pre-proposals is strongly encouraged for all projects because it provides an opportunity for KSWSC staff to benefit from, and interact with, the WSFT specialists. This is particularly important for less experienced KSWSC Project Chiefs. These pre-proposals do not need to be completed in the standard USGS proposal format; it is acceptable to submit conceptual project ideas for review.

Proposals are developed through discussions with customers or KSWSC staff and are based on guidelines and format indicated in WMA Memorandum 13.01 (U.S. Geological Survey, 2013a). In October 2012, the Water Mission Area instituted new procedures for proposal review. Proposals and their accompanying Job Hazard Analysis will be merged into one Microsoft ${ }^{\circledR}$ Word document (preferably a ".docx" version) and submitted to the SharePoint ${ }^{\circledR}$ Web site. The WSFTs Proposal Repository Gatekeeper guides the proposal through its process review, revision, and approval. The Job Hazard Analysis template is available locally at the KSWSC.

The final proposal submitted for Regional approval will include the following sections: Executive Summary, Introduction or Problem statement, Objectives and Scope, Relevance and Benefits, Approach, Quality-Assurance Plan, Products, References, Work Plan and Timeline, Staffing, Budget, and Safety (Job Hazard Analysis).

The WSC has a process for periodic resubmittal of proposals to the WSFT Proposal Repository whenever there are substantial changes in the objectives, methods, or approach for long-term (multiyear) studies relative to the original proposal.

\section{Work Plans}

The development of a project work plan typically begins in discussions with the cooperator, another Federal agency, and among the USGS KSWSC staff regarding a groundwater problem or need. At this point, an appropriately qualified 
person(s) is selected by the Section Chief to develop a project proposal in consultation with appropriate WSC discipline specialists, Section Chief, WSC Director, and experienced groundwater personnel.

Following Water Mission Field Team approval of the project, the proposal is developed into a standard project description by the Section Chief and a Project Chief is selected. This project description and a preliminary budget are entered into the project tracking software [currently (2013) BASIS+]. As the first assignment in connection with the project, the Project Chief will begin development of a detailed work plan that may involve a literature search of applicable reports, articles, data, and other relevant information; retrieval of relevant data from available databases to determine the availability of and the need for additional data; identification and corrections of errors or inconsistencies in the database; review of other USGS file data, such as field sheets, waterlevel records, geophysical logs, lithologic logs, National Water Quality Laboratory (NWQL) analytical sheets, or other original data; and some limited onsite reconnaissance. The work plan should summarize data-collection activities, data-storage plans, equipment and instrumentation needs, and technical approaches to data analysis and interpretation; describe products such as reports or journal articles, report outline(s), cost estimates, deadlines for each work element; define total personnel needs, availability of personnel, training needs, safety plan (job-hazards analysis), archival plans, and other elements as necessary; and provide deadlines for each work element. Requirements for work by various sections of the KSWSC, by the cooperator, or by contractors will be clearly identified and scheduled.

A project report plan and timeline will be developed as an integral part of the work plan. The report plan will identify the type, scope, intended audience, and length of all reports and will provide a preliminary outline of each report, including a description of primary illustrations, maps, and tables. Preparations of the work plan and report plan are to be accomplished in the first 10 percent of the project duration (that is, on a 1 -year project, this task will be accomplished in the first 5 weeks). To achieve this end, the Project Chief should confer with the Section Chief, WSC Groundwater Specialist, and any other persons internal or external to the USGS who may offer guidance or insight into the problem being addressed. The report timeline is discussed during the appropriate project review meeting.

The work plan and report plan will meet the financial and temporal limits determined for the study and will schedule submission of project reports so that Director's approval and Bureau approval can be obtained and so all reports can be published prior to the conclusion of project funding. The work plan will be reviewed by the Section Chief, WSC Groundwater Specialist, and the other WSC Discipline Specialists during quarterly project reviews and as needed. Review also may be sought from Region or Headquarters personnel, or from the cooperating agency. The Project Chief will revise the work plan in response to review comments.
If during development of the work plan and (or) the life of the project, it becomes clear that the technology, funding, personnel, or time indicated in the original project description is inadequate to meet project objectives, further negotiations on modifications to the previous proposal may be necessary with the cooperating agency, the WSC, and Water Mission Field Team staff. A modified work plan will be developed from the results of these negotiations.

The general personnel requirements of the project are determined in the early stages of project planning and work plan development and modified as needed during the project life. The qualifications of project personnel relative to the technical demands of the work will be determined by the Project Chief, WSC Specialists, and Section Chief.

The KSWSC encourages the following:

1. Work plans for programs with groundwater activities clearly state that the GWQAP will be implemented.

2. Work plans state Data-Quality Objectives and describe the strategies to collect data to meet the intended use (to the extent practicable). When developing Data-Quality Objectives, broader network needs are considered as well as immediate objectives. Data-Quality Objectives are those qualitative and quantitative statements developed by data users to specify the quality of data needed from a particular data-collection activity.

3. Work plans specify the means for cataloging and archiving all groundwater activities and files according to USGS policy (Hubbard, 1992).

\section{Project Safety Planning}

Because the collection of data in the field can be hazardous at times, the safety of field personnel is a primary concern. All personnel engaged in field or laboratory work for groundwater project activities must comply with applicable USGS safety and health standards, procedures, and guidelines as a condition of employment.

Field teams can face very different dangers in areas ranging from areas of high traffic to very remote locations. Field personnel often work under extreme environmental conditions (temperature, precipitation, high water). Field work involves the transportation and use of equipment and chemicals, and can require working with heavy machinery such as drill rigs. Additionally, field personnel may be exposed to waterborne and airborne chemicals and pathogens while sampling.

Beyond the obvious concerns regarding unsafe conditions for field personnel, such as accidents and personal injuries, the quality of the data also may be compromised when sampling teams are exposed to dangerous conditions. So that personnel are aware of and follow established procedures and protocols that promote all aspects of safety, the KSWSC communicates information and directives related to safety to all personnel. 
Training is provided by contract trainers (for example, Hazardous Waste Operation, 40-hour training) or by in-house training classes (for example, first aid training and defensive driving). In addition, periodic safety presentations are made on specific topics utilizing videotapes, memoranda, or guest speakers as appropriate. Specific required and mandatory training policies and procedures related to safety can be found on internal web sites accessible at the KSWSC.

A Job Hazard Analysis (JHA) must be prepared by Project Chiefs for all projects. The purpose of a JHA is to ensure proper work assessment, funding, and assignment of responsibility with regard to all project safety elements. The information contained in the project JHA must be communicated to assigned personnel before project work begins.

An individual is designated as the collateral-duty Safety Officer by the KSWSC Director. The duties of the Safety Officer include serving as a primary contact for all safety issues, coordinating and conducting training and inspections, identification and abatement of hazardous conditions, and promoting safety throughout the KSWSC. Personnel who have questions or concerns pertaining to safety, or who have suggestions for improving safety, should direct those questions, concerns, and suggestions to their immediate supervisor or the Safety Officer, as appropriate. Guidelines pertaining to safety in field activities are provided in chapter 9 of Lane and Fay (1997).

\section{Project Reviews}

All projects will be discussed at the WSC quarterly project reviews. During these reviews, the current status, findings, and future plans are compared to the project objective(s) and work plan to ensure that the project is making proper progress. Project technical issues also are discussed at this time. Plans for future products such as reports or journal articles are discussed during project reviews and initial deadlines for completion are set. The project review team will include the WSC Specialists when appropriate, Section Chief, and WSC Director. Assistance will be obtained from the Region technical specialists, the OGW, and the National Research Program as needed. In addition, external technical reviews of selected groundwater projects are performed on a 3-year cycle as part of the USGS-WMA technical reviews, conducted by the Offices of Groundwater and Water Quality, and the WSFT technical specialists.

\section{Data Collection}

The types of data collected, the standards governing the precision and accuracy of the data, and the frequency with which data are collected may differ among various groundwater projects, according to the particular objectives of the studies. The Project Chief must clearly document and provide to the project personnel, in sufficient detail, instructions regarding data collection so that the data needs of the project are satisfied. Routine and nonroutine data-collection activities and procedures are documented by project or support personnel and are recorded in appropriate field notebooks. These notes are to be kept with project files and archived upon project completion.

Supervision of field procedures and activities is an essential responsibility of the Project Chief, who must ensure through personal observation that field personnel are fully qualified. The WSC Groundwater Specialist or their designee (for example, a Field Office Chief) will review the data collection activities of all groundwater projects on a yearly basis. Training, including on-the-job, will be used to ensure technique competence or to rectify inadequacies.

Individual field practices are checked by the Section, Field Office Chief, or WSC Groundwater Specialist. The frequency and intensity of these checks generally are matched with each field person's individual capabilities and experience; however, even the practices of the most experienced and capable field personnel are checked on at least a biennial basis, with more frequent checks reserved for personnel of lesser experience.

\section{Documentation of Technical Procedures}

Procedures used for the collection of groundwater data are derived from a series of technical procedures documents, in technical memoranda, Techniques of Water-Resources Investigations, and Techniques and Methods reports, and a number of other publications. Groundwater technical procedures are summarized in Cunningham and Schalk (2011). This document includes everything from procedures on how to make a water-level measurement, to format of a permission letter for well drilling, to installation and operation of submersible pressure transducers. If it is necessary to deviate from the technical-procedure documents when collecting data, then these deviations must be described clearly in the project records and may lead to an update of the quality-assurance plan.

In the event that a technical-procedures document is not available for a planned groundwater activity, techniques of data collection and analysis are described in USGS (1980). This document contains discussions of all the primary types of groundwater data collection, together with extensive bibliographies relevant to each activity. Standards for groundwater data collection will be based on the methods outlined in that document, the references contained therein, or OGW and KSWSC GWPDs.

Deviations from approved technical procedures are documented by the Project Chief and reviewed by the KSWSC Groundwater Specialist to determine if the alternative approach is appropriate or if a formal revision of a relevant GWPD is warranted. New or revised GWPDs are reviewed by an independent reviewer and approved by the KSWSC Groundwater Specialist. 
- Reviews address applicability and appropriateness of the selected methods for the intended purpose; correctness of facts, figures, tables, and equations; completeness and clarity of step-by-step instructions and technical content; and an evaluation of the stated accuracy of the procedure.

- Approval of GWPDs used within the KSWSC is the responsibility of the KSWSC Groundwater Specialist. Upon approval, the new GWPD is placed in the KSWSC file and a copy is forwarded to the Regional WSFT's Groundwater Specialist.

\section{Documentation of Nonroutine Activities}

1. When data-collection methods are new, nonroutine, or research oriented, and involve a high degree of professional judgment or trial and error, an active record of the conduct, progress, and results of the data collection shall be maintained in a procedures notebook. These records shall be prepared and maintained in accordance with the following:

- Prior to use of a procedures notebook, the Project Chief shall consult with the WSC Groundwater Specialist concerning the appropriateness of a nonroutine method for planned data collection.

- Each procedures notebook entry shall include the names of the individuals performing the work, the date on which the work was performed, and the name of the individual making the entries.

- At the conclusion of the method development, procedures notebooks shall be placed in the project file.

2. The results of the technique developed in the procedures notebook shall be reviewed by the WSC Groundwater Specialist to ensure that work is proceeding in a technically appropriate and relevant manner.

3. If the technique that has been documented in the procedures notebook becomes a routine procedure for the USGS KSWSC, then a technical-procedure document shall be developed.

\section{Documentation of Groundwater Sites}

The selection of a groundwater site (well or spring) for data collection depends on variables such as project data objectives; location and accessibility of the site; well depth; well completion interval; and the availability of ancillary geologic, hydrologic, and geophysical data. Detailed guidance for groundwater site selection can be found in Lapham and others (1997) or a stratified random site-selection approach guidance can be found in Scott (1990). Wells may need to be installed, if existing sites that meet project data-collection objectives cannot be located.

Drilling of test holes and installation of monitoring (water level or water quality) wells requires permission from the landowner. At a minimum, oral permission must be documented with landowner's name and date permission given. If equipment is to be installed and left at the site, then written permission will be obtained from the landowner with name, contact phone number and address, date permission given, and signature. Form 9-1483 will be used for permission, but can be updated with site specific information. This form is available as an electronic form in the internal USGS webform system.

Water wells (including monitoring wells) drilled in Kansas must be done by a driller licensed by the Kansas Department of Health and Environment (KDHE). The well driller is required to file a water well completion record (WWC5 form) with KDHE detailing the well's location, depth, construction, and lithologic information for each water-well drilled. For more information about well-driller licensing and WWC5 forms, see http://www.kdheks.gov/waterwell/index.html.

Thorough documentation of well sites and data-collection activities are essential to the success of a groundwater project. Well-site documentation includes the creation and upkeep of well station folders that are used to store well-site information. The NWIS site files (also called GWSI header files) must be established in the NWIS database for well sites at which KSWSC groundwater activities take place. The NWIS site file for a new site will be established as soon as possible after its selection to facilitate entry of filed data (water levels or waterquality data) into NWIS. The KSWSC policy on the establishment of groundwater sites, NWIS site files, NWIS station folders, and required site-file documentation is described in the "Site Establishment" section. The Project Chief is responsible for adherence to the procedures in the "Site Establishment" section.

\section{Instrumentation}

All instruments, devices, and equipment (including steel tapes and electric tapes) used to collect groundwater data are categorized as instruments. Field personnel are provided with or need to acquire manufacturer's manuals or equivalent instructions on the use of instrumentation, such as electric and steel tapes, pressure transducers, data loggers, satellite datacollection platforms (DCPs), flow meters, and geophysical equipment. Training of field personnel is conducted by qualified individuals before field activities begin. Experienced Field Office Chiefs, Section Chiefs, and Project Chiefs generally provide training on instrumentation, but the WSC Groundwater Specialist will coordinate training on request.

Electronic data loggers, DCPs, or both, are used to collect continuous water-level data in groundwater wells. Field personnel use lap-top, palm-top, or tablet computers or replacement data cards to download data from the data loggers. Users 
are trained for the specific data loggers used in the individual offices.

To assist anyone inspecting and (or) servicing the recorder, a folder that includes a station description and levels summary that provides information about the well and data logger is located at each recorder well. Information listed includes well name, location, and altitude of measuring point (or land-surface datum, a description of the measuring point, and its height above land surface).

The type of instrumentation installed at a well site in Kansas is dependent on the types of data to be collected and the expected life of the site. Submersible pressure transducers are the typical water-level sensor used in KSWSC groundwater wells for continuous monitoring. Procedures for installation and operation of submersible pressure transducers are described in GWPD 16 (Cunningham and Schalk, 2011). The DCPs are used at all continuous-record well sites for data logging and data transmission.

It is the responsibility of the Section chief, in consultation with the Project Chief or the Field Office Chief, to determine what type of water-level recorder is used at well sites. Ensuring that instrumentation installed at well sites is properly serviced and calibrated also is the responsibility of the Project Chief or the Field Office Chief.

All well-site instruments are serviced on a frequency determined by the scope of the work. Accurate water-level measurement requires not only accurate instrumentation but also proper installation and continued monitoring of all system components to ensure accuracy doesn't deteriorate with time. To ensure that pressure transducers located at the well site record accurate water levels, a reference water-level measurement collected by tape down from a measuring point using a steel tape or an electric tape is obtained and compared with the water level measured by the pressure transducer during each site visit. Procedures for use of a steel tape are presented in GWPD 1 (Cunningham and Schalk, 2011). Procedures for use of an electric tape are provided in GWPD 4 (Cunningham and Schalk, 2011). Small differences (plus or minus 0.04 foot) between these water levels may exist; however, reasons for larger differences must be identified by servicing personnel. Consistent differences over time may be caused by a pressure transducer problem and the pressure transducer will be replaced. In the KSWSC, all groundwater field data including dates, times, water-level measurements, instrument problems, and remarks are entered into the Surface-Water Measurement and Inspection (SWAMI) program available for handheld devices and tablet computers. After returning to the office, the SWAMI files are uploaded to SiteVisit, a program that enters field data into NWIS. The reference water level also is entered into GWSI. Field data also can be documented on paper field sheets or in a field notebook if electronic devices are not available or not working. Then, after returning to the office, manual data entry into SiteVisit and GWSI is done.

To service field installations, field personnel are supplied tools, spare data loggers, spare pressure transducers, and batteries. Field personnel are responsible for the replacement (or repair if possible) of equipment within 3 days of detection of damage or malfunction, and are expected to have the site footnoted and temporarily removed from NWISWeb until the equipment is operating properly again. Battery voltages are checked during each site visit, and batteries are replaced when necessary. Rechargeable batteries removed from the site are recharged for future use. Nonrechargeable batteries that are replaced are disposed of properly. In addition, routine maintenance of instruments is conducted during each site visit.

Data collected with instruments determined to be out of calibration will be evaluated to determine the effect on the intended use of the data. Affected data will be discarded or limitations documented in the database and in any application of the data. All instruments used to collect data will be operated in accordance with the manufacturer's manual, unless otherwise documented. Modifications to the manufacturer's operating procedure will be appended to the manufacturer's manual. Operating procedures for submersible pressure transducers are included in GWPD 16 (Cunningham and Schalk, 2011).

The pressure transducers used in groundwater wells in Kansas include a water temperature thermistor that provides temperature correction data to the pressure transducer. In Kansas, these data are used as ancillary information for internal use only. NWISWeb access levels for the relevant data descriptor (DD) are set to two (all USGS) or three (host Center only), thereby blocking the data from reaching the public. The DD for secondary thermistor data is not marked as "primary" and these data are never flagged as approved. The station analysis for these sites should document what these data represent. Procedures for processing the water temperature data are described in OGW Technical Memorandum 2012.02 (U.S. Geological Survey, 2012a).

If funding is available to display, process, and approve secondary water temperature data, quality-assurance guidelines are addressed in USGS (2012a). The water temperature continuous record is worked using guidelines documented in Wagner and others (2006) and Bennett (written commun).

\section{Methods for Calibration of Graduated Steel and Electric Tapes for Measuring Water Levels}

The KSWSC uses steel tapes and electric tapes to collect water levels for comparison with those water levels measured by pressure transducers. Calibration of the measuring instrument is necessary for quality assurance and quality control of the groundwater measurements. Calibrations are performed annually. The KSWSC uses two procedures to calibrate steel tapes or electric tapes used to measure water levels. These procedures were adapted from those used in the Arkansas Water Science Center. The steel tapes or electric tapes are replaced if there are numerous breaks in the tapes, kinks, significant tape stretch, or numbers (in the case of steel tapes) become difficult to read. In the KSWSC, electric tapes are sent back to the vendor every $2-3$ years for cleaning and general maintenance. 
If this maintenance includes a calibration check, results of the calibration may be used in place of the following two procedures for that year.

\section{Basic Method}

The following material and instruments are required:

- A calibration steel tape graduated in feet, tenths, and hundredths of feet. The calibration steel tape will be used only for calibration and will be as long as the longest measuring tape. The calibration tape must be clearly identified to prevent use in field measurements, and will be secured when not being used for calibration.

- The steel or electric tape will be calibrated.

- Laptop or tablet computer will be used for recording calibration corrections.

- Reasonably level section of ground the length of the calibration tape, usually black top or cement (parking lot).

Calibration assumptions and limitations:

- Steel tapes have similar stretching coefficients when the width and gage are similar.

- Electric tapes with light weight probes and small gauge wires will have minimal stretch.

Calibration method advantages:

- Provides a reasonable calibration of steel and electric tapes and a history of the condition of the tape throughout the equipment period of use.

- Able to visually align the steel and electric tapes side by side with the calibration tape.

- A close visual inspection of calibration between the lengths of the measuring tape and the calibration tape are performed by personnel.

- Minimal difficulty in reading differences in lengths over calibration intervals.

- Least likely to damage or wear calibration tape.

- The most time efficient method.

Calibration method disadvantages:

- Does not take into account variable stretching coefficients for tapes that are constructed from different materials from the calibration tape.

- Two persons required to perform calibration.

Calibration instructions:

- A minimum of two personnel is necessary.
- Assign a unique identifier to every measuring tape that will be calibrated. The unique identifier must be permanently marked on the measuring tape. Unique identifiers should not be reassigned when a tape is replaced due to damage or loss. A new unique identifier will be assigned whenever a new measuring tape is purchased.

- Locate an area where the tapes can be laid down on a smooth, level surface for the entire length of the calibration tape.

- Determine a calibration interval, a distance interval that will be calibrated in segments throughout the length of the tapes. A larger calibration interval will have a greater error in the correction. Smaller calibration intervals will provide better accuracy in the correction and increase the time necessary for calibration and calculation of the correction. The calibration interval should not exceed 100 feet.

- Place the calibration tape and the measuring tape parallel, stretched to full length, on the level surface. Align the zero foot marks of the two tapes, and the first person holds the tapes in place. If the measuring tape has been broken off or shortened, align the first unit foot mark (that is, if tape is broken off at 6.57 feet, align at 7 -foot mark). If the tape is short, record the starting foot interval in the calibration record book.

- The second person proceeds to the end of the first calibration interval, pulling both tapes to remove the slack and align the tapes parallel for the length of the calibration interval. Do not pull with enough force to stretch or remove kinks from the tapes, only enough to align the tapes and remove any slack.

- The second person reads the value of the measuring tape aligned next to the end of the calibration interval on the calibration tape, and then records the correction for the interval in the calibration record book. The first person then moves the end of the calibration interval, aligns the tapes for the second interval, and the process repeats for the length of the measuring tape. The calibration interval in table 1

Table 1. Example of a calibration record for steel tape or electric tape.

\begin{tabular}{ccc}
\hline \multirow{2}{*}{$\begin{array}{c}\text { Length } \\
\text { (feet) }\end{array}$} & \multicolumn{2}{c}{ Tape A04 } \\
\cline { 2 - 3 } & Interval & Cumulative \\
\hline $0-100$ & -0.03 & -0.03 \\
$100-200$ & -0.05 & -0.08 \\
$200-300$ & -0.11 & -0.19 \\
$300-400$ & -0.07 & -0.26 \\
$400-500$ & -0.04 & -0.30 \\
\hline
\end{tabular}


is 100 feet. At the 100 -foot mark on the calibration tape, the measuring tape aligned at 100.03 feet, the correction is recorded as -0.03 feet. The next segment is calibrated by holding the two tapes aligned at the 100-foot mark, then reading the correction for the 100-200-foot interval. When the length of the measuring tape has been calibrated, a cumulative correction is calculated for the calibration intervals.

- The process is repeated for the next measuring tape. When complete for all measuring tapes, the calibration data entered into an electronic file will be placed in a designated computer directory accessible to KSWSC personnel. The directory location will be more clearly described once the transition to electronic data management is complete.

\section{Well Method}

Materials and instruments:

- A steel tape graduated in feet, tenths of a foot, and hundredths of a foot is used for a calibration tape. The calibration steel tape will be used only for calibration and as long as the longest measuring tape. The calibration tape must be clearly identified to prevent use in field measurements, and will be secured when not being used for calibration.

- The steel or electric tape to be calibrated.

- Laptop or tablet computer will be used for recording calibration corrections.

- An observation well, free of obstruction, with the water level at greater depth than the calibration interval. The well depth must be greater than the length of the calibration tape.

Assumptions and limitations:

- The measuring tape is measuring along the same pathway in the well as the calibration tape.

- Variations in the well casing are not differentially altering the water-level measurements.

Advantages:

- Provides a reasonable calibration of steel and electric tapes, and a history of the condition of the tape throughout the equipment period of use.

- Calibration method duplicates water-level measurements.

- Accounts for variations in stretching between the calibration tape and the measuring tape.

- Only one person necessary for calibration.
Disadvantages:

- May cause wear or damage to calibration tape. If calibration tape is excessively worn or damaged, it will need to be replaced.

- The least time efficient method.

- Unable to determine if the measuring tape is measuring along the same pathway in the well as the calibration tape and if variations in the well casing are differentially altering the water-level measurements.

Instructions:

- Assign a unique identifier to every measuring tape that will be calibrated. The unique identifier must be permanently marked on the measuring tape. Unique identifiers should not be reassigned when a tape is replaced due to damage or loss. A new unique identifier will be assigned whenever a new measuring tape is purchased.

- Determine a calibration interval, a distance interval that will be calibrated in segments throughout the length of the tapes. A larger calibration interval will have a greater error in the correction. A smaller calibration interval will provide better accuracy in the correction and increase the time necessary for calibration and calculation of the correction. The calibration interval should not exceed 100 feet.

- Locate a series of unobstructed observation wells in good condition with a water level in each calibration interval.

- Measure the water level in the well using the calibration tape. Record the water level according to GWPD 1 (Cunningham and Schalk, 2011) for a graduated steel tape.

- Measure the water level in the well using the measuring tape. Record the water level according to the GWPD 1 (Cunningham and Schalk, 2011) for either a graduated steel tape or an electric tape.

- Compare the two measurements, calculating the correction for the measurement tape by subtracting the measurement tape water level from the calibration tape water level. Record in the calibration record book.

- Proceed to the second well with a water level in the second calibration interval. Repeat the measuring process for the calibration and measuring tapes. Calculate and record the correction for the second water level.

- Continue this process until a calibration correction has been determined in each calibration interval.

- Use the measurement corrections to interpolate a correction for the calibration intervals. 
- Example The calibration interval is 0 to 50 feet. Measurement in the first well produces a correction of -0.02 feet for a 30.01 -foot measurement. Measurement in the second well produces a correction of -0.05 feet for a 89.98 -foot measurement. The interpolated correction for 0 to 50 feet would be -0.03 feet.

- The process is repeated for the next calibration interval. When complete for all measuring tapes, the calibration data from the calibration record book is entered into an electronic file. The file is placed in a designated location accessible to KSWSC personnel.

\section{Abandonment of U.S. Geological Survey Monitoring/Observation Wells}

The USGS observation or monitoring wells that are no longer needed or useful for the collection of groundwater data will be abandoned following guidelines of the Kansas Department of Health and Environment (KDHE, 2011).

The USGS observation or monitoring wells that are still useful for the collection of groundwater data but are no longer needed by the USGS for data collection can be transferred to other agencies. Transfer of ownership of the well requires completion of the well-transfer agreement, Form 9-3106, that is available on an internal web site at the KSWSC.

Documentation of abandonment or transfer of ownership of a USGS monitoring/observation well shall be placed in the site-file folder and the NWIS site file will be updated to indicate that either the site was abandoned and destroyed or that ownership was transferred.

\section{Identification and Control of Samples}

During the course of many groundwater investigations, samples of various types of earth materials are collected to supplement field observations or for laboratory tests, analyses, and measurements that are not possible to perform in the field. Sample types include rock core, drill cuttings, soil, and outcrop, and are referred to as specimens in the Center DataManagement Plan (Brunett and all, 1997).

The sample-control system involves recording information pertinent to each sample or set of samples on a field form or in a field notebook. Sample-control system documentation is placed in the project file and archived with project records. A unique identifier is assigned to each individual sample and marked on the sample or sample container. Information recorded on the field form or in the field notebook includes the following:

1. Unique identifier.

2. Type of sample.

3. General sample description.
4. Source location.

5. Date and time of collection.

6. Reference to GWPD, such as GWPD 16 (Cunningham and Schalk, 2011), procedures notebook, or other technical procedure documents used for describing sample collection, handling, preservation, transportation, and storage.

7. Storage location of the sample.

Quality-assurance procedures involving instrumentation will be conducted as described in the Quality Assurance Plan for District Groundwater Activities (Brunett and others, 1997).

\section{Data Analysis}

The KSWSC uses numerous methods and procedures for analyzing the groundwater data collected onsite including statistical analysis, graphing, contouring, spatial-data display, and numerical modeling. All analyses receive extensive review by supervisors, discipline specialists, and colleagues prior to publication. More rigorous review procedures are provided for analyses involving nonroutine statistical analyses, aquifer testing, and numerical modeling. Data-analysis techniques are identified, at least preliminarily, during the proposal development/review process and development of the project work plan. Data-analysis techniques are reviewed through the project review process as warranted by the proposed activity.

Data-analysis procedures are referenced in the publication presenting the interpretation. Aquifer-test analyses and documentation follow policy in OGW Technical Memorandum 2009.01 (U.S. Geological Survey, 2009) and are reviewed and approved by the WSC and Water Science Field Team Groundwater Specialist before release to the public. Groundwater flow and transport models are quality assured through the project review process culminating with the review, model archive, and approval by the Water Science Field Team Groundwater Specialist as outlined in OGW Technical Memorandum 2011.01 (U.S. Geological Survey, 2011). Documentation of models in reports follows the guidelines described in OGW Technical Memorandum 94.02 (U.S. Geological Survey, 1994). If results from a non-USGS computer program will be used, the program is tested to verify results as described in OGW Technical Memorandum 97.01 (U.S. Geological Survey, 1997b).

If a data-analysis procedure is used and it is not one previously established and documented by USGS, the procedure is described, reviewed, and approved by the appropriate discipline specialist and the WSC Director prior to its use. The description includes enough detail so that reviewers can determine the validity of the analysis. Analyses that require only a short description are included in the report where the data analysis is used. Longer descriptions must be stand-alone documents. All documentation of new data-analysis procedures are kept in the project file. 
Data-analysis techniques are described in several publications listed on the OGW Web site (http://water.usgs.gov/usgs/ $o g w /)$, Techniques of Water Resources Investigations (http:// water.usgs.gov/pubs/twri/), OGW Technical Memoranda and groundwater notes (http://water.usgs.gov/usgs/ogw/techmemo. html and http://water.usgs.gov/admin/memo/GW/auto.html), American Society of Testing and Materials (ASTM) standards (search "Individual ASTM Standards" by "aquifer" or "groundwater" at http://www.astm.org), and other scientific literature, such as journal articles, USGS reports, and groundwater text books. Copies of many of these publications are available from libraries in the KSWSC or from the USGS library at the Denver Federal Center in Lakewood, Colorado.

\section{Data Management Plan}

Data management is an integral part of the work performed by KSWSC staff. Without a DMP, original data may be lost, old data needed for a new study may be difficult to find, or archiving procedures would not be understood by all staff. The DMP describes the procedures used for data processing, review, storage, and archiving. The DMP describes the roles and responsibilities of the WSC's staff and the data management process for the groundwater and geospatial data areas of the USGS in Kansas. The DMP also describes the final archiving of data collection, interpretive work, and research done by the KSWSC. Archiving is important because it is the final step in a research, interpretive, or data-collection project; a systematic process for storing data and information to protect it from alteration; and final documentation of information and calculations needed to reproduce published results. The following sections describe the progression of data management from collection to archiving.

After groundwater data are collected, the data are processed using one or more procedures, such as the application of time, datum, and water-level measurement corrections, and then are stored in computerized or physical files. Descriptive information on data-collection sites, such as well construction data and location, also are stored. Where possible, all groundwater data collected by the KSWSC is stored in NWIS and archived, so that KSWSC personnel, WMA personnel outside the KSWSC office, and the public have access to the data. Storage of groundwater data in a single database (NWIS) also enables interpretations to be more easily verified and repeated, and ensures that data will remain accessible after a project or program is completed.

Because the public has easy access to groundwater data through the NWISWeb Interface (http://waterdata.usgs.gov/ nwis/gw) and Groundwater Watch (http://groundwaterwatch. usgs.gov/) and we have a duty to maintain high-quality records, procedures for processing and reviewing groundwater data will be thorough and rigorously applied to ensure that records designated ready for the web are accurate once approved.

\section{Pre-Project Data Management Planning}

All new projects, regardless of whether they are longterm data-collection networks or shorter-term scientific investigative studies, will begin with a meeting that includes the Project Chief, appropriate data collectors, the Data Chief (or appropriate Field Office Chief), the Studies Section Chief, the Water-Quality Specialist, the Groundwater Specialist, and the Database Administrator prior to the start of site establishment and data collection. The objective of this meeting is to describe the data needs for the project such as, but not limited to, publication needs, sensitivity of data released to the public by way of NWISWeb, responsible parties (that is, Project Chief and project staff), and any nontypical data entry protocol that is needed (for example, data analyzed or collected by non-USGS labs). After this meeting, it is the responsibility of the Project Chief to develop a project work plan that will be reviewed and discussed at the next scheduled project review meeting. The project work plan will include a description of data-collection activities and timelines, data-analysis activities and timelines, and report plans and timelines. Development of the work plan is discussed thoroughly in the "Work Plan" section of this report.

The pre-project meeting, at a minimum, should consist of a description of the intended management plan for the flow of data throughout the course of the project. To facilitate this, the following list of questions will be addressed prior to the start of the project:

1. What is the objective of this project?

2. Who are the cooperators? What are the account number and project number? Who are the responsible parties?

3. Are these data sensitive to public release prior to publication?

4. What are the plans for publication? Will a project data review be needed?

5. Are continuous data monitoring sites going to be established? What type of instrumentation will be needed? Who will be responsible for maintaining the monitoring sites?

6. If water-quality data are being collected, what are the planned parameter codes?

7. If water-quality data are being collected, to what lab(s) will these data be sent? Are these USGS labs? If not, have these labs had our quality-assurance verification for previous projects?

8. If water-level or water-quality data are being collected, what is the sample frequency?

9. Are there data collected in this project that cannot be stored in NWIS? 
10. If yes, how are those data going to be stored and archived?

11. If you answered no to question 9 , but are still planning on storing sample data outside of NWIS, why are you intending data not to be stored in NWIS?

12. Are new sites to be created, or are existing sites to be used? Will permissions to install equipment or collect samples be needed at the new sites?

13. What is the expected duration for the project?

After the project data collection and analysis have been initiated, the project will begin and data may be collected, analyzed, or both. It is the responsibility of the Project Chief to manage all active electronic and paper data files during the course of the project. If the Project Chief wishes to delegate this responsibility to a member of the project staff, that role will be documented in the project plan. The Project Chief or designee will initiate a site folder where data will be kept during the course of the project.

Once the project has ended, all electronic files will be archived in appropriate computer directories, and paper files will be locally archived in the KSWSC office, by station identification number or special project file location. It is the responsibility of the Project Chief or assigned party to ensure that all archived records are returned to the proper location at the end of the project. National archival of paper documents also may be required at a later date.

\section{Site Establishment}

Project staff should determine sampling locations prior to the start of data collection. There may be occasions where this task cannot be accomplished; for example, when groundwater wells are inventoried in the field on the same occasion as sampling, and sites cannot be established until return from the field trip.

To initiate site entry, a paper site entry form (in digital form once transition to electronic data management is complete) will be filled out. It is the responsibility of assigned project staff to fill out necessary site forms. A list of appropriate site forms is available locally at the KSWSC.

The personnel who fill out the form should ensure that proper naming and coding protocols are followed. The Database Administrator can provide assistance with this task. At minimum, the following site information needs to be entered, or if it is not possible to obtain, needs to be addressed prior to form submission:

1. Agency code.

2. Station name.

3. Station type.

4. Water Science Center, country, state, county.
5. Latitude, longitude, latitude/longitude accuracy, latitude/ longitude method, latitude/longitude datum.

6. Altitude, altitude method, accuracy, datum.

7. Hydrologic unit code.

8. Landnet location.

9. Map name, map scale.

10. Agency use.

11. Use of site.

12. Data reliability code.

13. Well depth (or hole depth), source of depth data.

14. Aquifer information where available.

15. Construction information also is desirable if the well was drilled by USGS or this information is known.

The current list of definitions for item codes and instructions on coding conventions can be found by selecting GWSI under "Manuals and Documentation for NWIS Software." This information is available on an internal web site at the KSWSC. See the DBA and appendix 1 for KSWSC stationnaming conventions.

Once the site form has been filled out, it is given to the KSWSC DBA for review (see below) and then a GWSI site entry file is created for submission that matches the paper form that was filled out. The DBA has the responsibility of checking the following components of the site file:

1. Ensure that the new station is not a duplicate site and does not already exist on the local NWIS host (or another NWIS host, if it a shared site), under another station identification (or the same station identification), or that there is not another station identification number that is close enough to be listed under the same station identification.

2. Check that the station name follows appropriate conventions.

3. Ensure that the form has been filled out properly and that required items are entered or at least addressed.

4. Check that the file has been completely filled out with information available on the site form.

5. Check the site file to make sure that the information is logical using GWSI entry edit/check programs.

If the DBA determines that the site file needs corrections or that there is missing or incorrect information, the file will be turned over to the project staff to address these issues. Once the DBA determines all requirements have been met, the DBA can then enter the site file into NWIS.

Site entry also can be done using the Management and Population of Sites (MAPS) application of NWIS. The MAPS program is a graphical user interface that allows entry and 
editing of sites in the NWIS site file and uses geographical datasets to populate the spatial fields for a site. An interactive geographic information system map is provided for visual reference (Seanor and others, 2013).

The MAPS program automatically populates some fields on the site information list such as hydrologic unit code and landnet location. Other site information is entered through the graphical user interface. The MAPS manual is located at an internal web site available at the KSWSC. Select "MAPS" under "Manuals and Documentation for NWIS Software."

A site-file folder will be established for each data-collection site. The site-file folder contains all the information about the site. It is the responsibility of project staff to gather the necessary information for this file. Some of this information may be gathered later on in the project after data collection has begun. Some site information is stored in computer locations or databases. Station descriptions are stored in the Site Inventory Management System (SIMS). JHAs, level notes, permits, and photographs are stored in folders in the archive directory at the KSWSC. Site visit information is collected in SWAMI and uploaded to SiteVisit, the program used to input field data and information into NWIS. The bulleted information below lists the components that may be included in the site-file folder:

- Original water-level field notes or field note books.

- Driller's log, geophysical logs, and well-construction information.

- Aquifer test, slug test, and other hydraulic data. (Plans are to establish an archive folder for aquifer test information).

- Quality-assurance reports for non-USGS labs used.

- Copies of analytical services request forms (laboratory login sheets).

- Water-quality analytical laboratory related forms (field alkalinity, bacteria, biological oxygen demand, and so forth).

- Water-quality sample rerun and verification (requests, results, and interpretations).

- Original data related to establishment of a measuring point (this information also may be documented in station description stored in SIMS).

- Correspondence pertaining to the well site.

The site-file folder contains the necessary information to verify data in a report or database. The files for each data-collection site are maintained in folders in the office of the project staff or Project Chief while the project is active. Any changes in data (for example, water-quality reruns, incorrectly located sites, math errors in levels or other calculations) are explained, dated, and initialed in the station folders, and appropriate updates are made to the databases in conjunction with the water-quality or other discipline specialists. All changes to a site will be noted in the site-file folder. After a project report has been approved, or if no report is to be published after the project has been completed, the site folders will be archived in appropriate electronic directories or filed in designated file cabinets in the WSC. Additional details related to site establishment can be found in appendix 1. Also, information related to establishing real-time sites can be found in appendix 2 .

\section{Data Processing and Review}

After groundwater data have been collected in the field according to procedures described in the "Data Collection" section of this report, these data are processed and reviewed to ensure the data are of high quality.

Procedures used in data-collection programs and projects receive external review every 3 years through the OGW Discipline Review process. Processing of electronic data, application of shifts and data corrections, correction of transducer drift, storage in NWIS, and so forth ensure quality data and consistency among the offices. Continuous-record groundwater records are reviewed by experienced hydrologic technicians, field office chiefs, or Project Chiefs and documented in the Records Management System (RMS). Data for project and research activities are reviewed throughout the year by project staff and during annual project and management reviews.

Data used in interpretive projects and research activities are reviewed for the accurate processing application of appropriate techniques by the Project Chief, colleague reviewers, and Regional discipline specialists.

\section{Groundwater Site Information}

The GWSI site schedules are reviewed by the Database Administrator prior to establishment of the NWIS site files (site header files) to ensure that the site schedules are complete and have valid entries for all required fields, that the proposed site does not already exist in NWIS, that coded values are consistent with supporting documentation, and that the site-file folder contains the documentation required for groundwater sites. Questions are referred to the Groundwater Specialist.

\section{Water-Level Data}

Initial processing of discrete and continuous data is completed as soon as feasible after the site visit is completed. The Studies Chief or Data Chief may designate the timeliness of this work on an "as needed" basis. Unless designated otherwise by the Section Chiefs, each field person is responsible for the initial record processing of their continuous-record stations.

A review of field data-collection sheets is made prior to entering groundwater data into NWIS. Errors of omission (of required data) and in calculations are corrected and annotated on the field data-collection sheet prior to entry of 
data in NWIS. After data are entered into NWIS, they are cross checked with the field data-collection sheets or other documentation.

\section{Discrete Data}

Discrete water-level data are collected manually from wells on an occasional basis, especially at all continuousrecord sites, for comparison with water levels collected by pressure transducers. Equipment used for these measurements includes steel tapes and electric tapes. Prior to input of these discrete measurements into the GWSI database, a plot of historical water-level measurements must be performed and compared to the new measurement as a quality check to identify anomalous data. Discrete water-level data are then entered into the GWSI database for storage and retrieval as described in OGW Technical Memorandum 2006.01 (U.S. Geological Survey, 2006a). Discrete groundwater data collected during a site visit at a continuous water-level monitoring site is reviewed and approved by an experienced hydrologic technician or Field Office Chief as a part of the continuous record process. Other discrete groundwater data are reviewed and approved by project staff. Additional policy on review and publication of discrete data is in OGW Technical Memorandum 2012.03 (U.S. Geological Survey, 2012b). In the KSWSC, all discrete water levels measurements collected in the field are entered into SWAMI. Once in the office, the SWAMI files are uploaded to SiteVisit. Currently (2013), there are only a few staff that have access to GWSI. Once field staff have uploaded the water-level data to SiteVisit, they communicate this to one of the GWSI-trained staff who take the water level from SiteVisit and enter it into GWSI. The KSWSC uses this procedure because there are not enough discrete water levels to make it necessary to give all field staff access to GWSI. This process will be streamlined using mobile devices as software and hardware become available.

\section{Discrete Furnished Data}

The USGS policy related to accepting furnished records is described in Water Resources Division (WRD) memorandum 2008.01 (U.S. Geological Survey, 2008b). All furnished records must be reviewed by USGS personnel before they are made available to the public through NWISWeb.

Water-level data provided by the city of Wichita are entered manually into NWIS with the water-level "ready for web" flag set to "C" (conditional). Hydrographs of the data are reviewed by project staff. Data that look reasonable or can be verified after discussion with city staff are retained. After data has been verified, the "ready for web" flag is changed to "Y" and the data are served to the web.

Water levels from Kansas Geological Survey (KGS) Water Information Storage and Retrieval Database (WIZARD) (http://www.kgs.ku.edu/Magellan/WaterLevels/index.html) undergo a series of quality-assurance checks by KGS before they are made available to the public in the online version of the WIZARD database. These quality checks include in-field checks using KGS in-house "Water Witch" and "Water Bug" software that checks the location of each well against that stored in WIZARD and verifies that each water-level measurement falls within a certain threshold of the historic trend of past measurements. Many measurements undergo a further statistical review. The KGS also reviews all comments and remarks for further information, which may require removal of some water-level measurements.

The High Plains Monitoring Project personnel obtain a download of water-level and other associated data stored in WIZARD directly from KGS. This download is more complete than the data available online from WIZARD. For example, currently (2013), the date and time of measurement of the water level are included in the download from KGS, but only the date is included in the online version WIZARD. This download undergoes further statistical checks and inspection by the High Plains Monitoring Project staff and checks to avoid duplicating data that may already be in NWIS. Then files are created using Site-Specific Water-Use Data System (SWUDS) templates to create input files for upload into the KSWSC NWIS database. The High Plains Monitoring Project staff adds water levels from about 1,000 sites annually to NWIS using this method. Any problems present during the USGS review are discussed with appropriate KGS staff.

The Equus Beds aquifer staff review hydrographs of the data in WIZARD before downloading the data from the KGS WIZARD database. The download is done through either an ArcGIS database connection directly to the WIZARD Oracle database or through a download from the online version of WIZARD. The data are added to NWIS after properly reformatting. The Equus Beds aquifer staff adds an additional several hundred water levels to NWIS annually using this method.

\section{Continuous Data}

All continuous water-level data from wells in Kansas are collected by use of a pressure transducer that digitally collects and records a time stamp and data value. Continuous data stations in Kansas are equipped with a DCP that logs data and transmits these data via satellite. After decoding the received raw data file, a file is created that automatically moves these data into the Automated Data Processing system (ADAPS). These data then are available through NWISWeb.

Continuous water-level data are worked, checked, and reviewed and approved in accordance with the Continuous Records Processing policy (U.S Geological Survey, 2010a). In the KSWSC, staff are provided 40 days from site visit to work the water-level data record and 20 days to check and review the record. Continuous water-level records are worked and checked by Data Section and Studies section staff. Continuous water-level records are reviewed and approved by experienced hydrologic technicians or field office chiefs.

The continuous water-level record process begins shortly after the site visit. Site visit information in ADAPS such as condition of pressure transducer and water-level difference between pressure transducer and discrete water-level measurement are reviewed for completeness and appropriate updates 
are made. A graph of the continuous water-level data is analyzed to determine if periods of erroneous data exist. Erroneous data are deleted from ADAPS. The discrete water level collected by tape down during the site visit is compared with the water level collected by the pressure transducer to determine if a correction to the continuous data is needed. Waterlevel corrections are applied if these differences exceed plus or minus 0.04 foot. When to begin the data correction is determined from analysis of the time series graph. Datum corrections based on station levels are applied in a similar manner. With few exceptions, for each continuous-record groundwater station operated by the KSWSC, a single water level, collected at 12 p.m., is stored as the daily value. The last step in the records process is to document the quality of the water-level data, magnitude and timing of the data or datum correction(s), and explain periods of erroneous record in the station analysis that is written in RMS and stored in SIMS.

\section{Aquifer-Test Data}

Aquifer-test data represent a unique set of water-level and other data that are used to determine aquifer properties such as specific capacity, hydraulic conductivity, transmissivity, or storage coefficient (Stallman, 1976). Aquifer test water-level data are not stored in ADAPS or GWSI. The aquifer-test data are contained in the site-file folder for the principle well(s) involved. The site-file folder will be identified by the USGS site identifier and contains data and analyses for the aquifer test. Aquifer-test data are processed using approved USGS techniques and procedures described in Stallman (1976). Also, guidance on preparation, approval, and archiving of aquifertest results are presented in OGW Technical Memorandum 2009.01 (U.S. Geological Survey, 2009). The aquifer-test data and analysis must be reviewed and approved by the KSWSC groundwater specialist as well as the Water Science Field Team Groundwater Specialist prior to publication. The approved aquifer test analysis is stored in the KSWSC Aquifer-Test file folder.

\section{Well-Integrity Tests}

All groundwater wells funded under the Collection of Basic Records (CBR) program are required to undergo a routine evaluation of well integrity according to procedures noted in OGW Technical Memorandum 2012.01 (U.S. Geological Survey, 2012c). KSWSC plans to do well-integrity tests on all continuous-record groundwater sites and expand these tests to wells where discrete water-level measurements are made. The procedures include office checks and field checks. Water-level fluctuations are checked as groundwater records are worked to determine change in well performance. Any performance problems are noted in the record station analysis. At each site visit, the physical condition of the well and well installation is noted and recorded on the field note. Annually, total depth of the well is checked using procedures in GWPD
11 (Cunningham and Schalk, 2011). If the recorded depth of the well has changed significantly, or the depth indicates that the effective open-screen length has decreased significantly, then well integrity could be compromised and additional testing may be necessary. The total depth measurement and any well problems are documented during the site visit. Types of hydraulic tests for well integrity are described in appendix 3. Results of well-integrity tests are documented in the station analysis for continuous-record sites and stored in the station folder. For other wells, results of well-integrity tests are stored in the station folder.

\section{Groundwater Flow and Transport Model Data}

Groundwater flow and transport numerical models typically consist of many electronic files in various formats (binary, ascii, text, executables, and so forth). These datasets typically are compilations and interpolations from other datasets. The model files must be approved before being cited in USGS reports or information releases. Policy information regarding storage of groundwater flow and transport model data can be found in OGW Technical Memorandum 2011.01 (U.S. Geological Survey, 2011). Policy on documenting the use of groundwater simulation in project reports is discussed in OGW Technical Memorandum 1996.04 (U.S. Geological Survey, 1996).

\section{Data Storage and Archiving}

Beginning October 1, 2013, the KSWSC began transitioning to electronic data management of all hydrologic data and records including data and records archiving. Electronic project folders and station folders will be set up to store appropriate documents. Any paper documents (field notes, permits, and so forth) will be scanned and saved to the appropriate electronic folder. Throughout this section various computer directories where groundwater information may be archived are mentioned. As the transition to complete electronic data management progresses, these locations may change as the process is developed more fully. These changes and full documentation of KSWSC Electronic Data-Management process will be included in the next update of this plan.

According to USGS policy, all original data that are published or support published scientific analyses shall be placed in archives (WRD Memorandum 92.59 (U.S. Geological Survey, 1992); Hubbard, 1992). Original data-from automated data-collection sites, laboratories, outside sources, and nonautomated field observations - are unmodified data as collected or received and in conventional units (engineering units, usually with a decimal). Original data will be preserved in this form, no matter how they may be modified later (Hubbard, 1992). Original data on paper include field notes, field measurements, analytical services request forms, water data listings of data entry (WATLISTs), continuous water-quality monitoring records, and calibration notes. 
Archiving project information after a project has been completed is the responsibility of the Project Chief. Project information subject to archiving includes original data, such as pertinent correspondence, project proposals, field notes, field maps, measured data not stored in NWIS, and digital information from project directories written to compact disk. Project information is archived either in files stored at the USGS KSWSC office or at the National Archives and Records Administration. Some original field data from basic data-collection programs (prior to 2000) are archived at the National Archives and Records Administration. Currently (2013), data program field data are stored in NWIS. The WSC Director or Project Chief has primary archival responsibility, and the Section Chief is responsible for providing support and guidance to Project Chiefs in meeting their archival responsibilities.

All groundwater data collected as part of the routine data collection in the KSWSC must be stored in NWIS. In addition, data collected by other entities (agencies, cooperators, education and research organizations, and consultants) that are used to support published USGS documents, but are not published or archived elsewhere, and can be accommodated by NWIS, shall be entered and stored in NWIS, either GWSI or ADAPS. Policy related to accepting furnished records is described in WRD memorandum 2008.01 (U.S. Geological Survey, 2008b). The GWSI and ADAPS are maintained locally by their respective Database Administrators, and both are components of the NWIS. Computer files of data and information are backed up and archived as part of standard KSWSC computer operations by the Site Administrator. If a project or program's dataset cannot be incorporated into a standard database, the data will be archived with the project files upon completion of the report or study.

\section{Discrete Data}

Field notes documenting discrete water-level measurements are to be stored in the station folder with the Project Chief or project data collector throughout the duration of the project. Site-file folders are to be archived in the KSWSC office on project completion. Discrete water-level data are stored and archived in GWSI as noted in OGW Technical Memorandum 2006.01 and 2012.03. Water-level measurements made with a water-quality sample are stored in GWSI and QWDATA (water-quality system of NWIS). Discrete groundwater-level data, furnished by KGS and the city of Wichita, also are stored in GWSI. These data are used in many reports produced for the city of Wichita, especially those dealing with the Equus Beds study, and by the High Plains Monitoring Project.

\section{Continuous Data}

Field notes documenting water-level measurements that are made in the field to check the continuous recorder (pressure transducer) are stored in the site-file folder throughout the duration of the project. If field data are collected on an electronic device in SWAMI, the SWAMI file is uploaded to SiteVisit upon return from the field. SWAMI files are archived in a directory available at the KSWSC. Station folders are archived in the KSWSC office on project completion. Reference water-level measurements made by tape down during site visits are stored and archived in GWSI. Continuous waterlevel data that are transmitted via DCP are stored and archived in ADAPS and available from NWISWeb.

\section{Aquifer-Test Data}

Aquifer tests are archived as outlined in OGW Technical Memorandum 2009.01 (U.S. Geological Survey, 2009). Approved aquifer-test data are archived in the Aquifer Test folder in the KSWSC data archive directory at ||Sps3dkslwr| data $\mid$ Data_Archive, an internal directory at the KSWSC. Any paper information related to the aquifer test is scanned and saved in the KSWSC Aquifer Test folder. These files are under the oversight of the KSWSC Groundwater Specialist. Digital water-level data and analyses are archived electronically in the KSWSC Aquifer Test archive. Resulting values (that have been approved by the Water Science Field Team Groundwater Specialist) for specific capacity, hydraulic conductivity, transmissivity, or storage coefficient are entered into GWSI where they are stored and archived.

The KSWSC has not completed any aquifer tests recently (2013). Past aquifer-test data and files are stored in a file cabinet located in the KSWSC. The Groundwater Specialist is responsible for the contents of this cabinet.

\section{Groundwater Flow and Transport Model Data}

Procedures for temporary and permanent storage of computer models follow guidelines described in OGW Technical Memorandum 2000.02 (U.S. Geological Survey, 2000b). Subdirectory ||$s p s 3 d k s l w r|d a t a|$ his_proj 1 |gwmarciv, available at the KSWSC contains the groundwater model archives for the USGS KSWSC. The KSWSC Groundwater Specialist is responsible for the contents of the subdirectory and, along with the KSWSC System Administrator, has read and write access. All others have read-only access. The groundwater model archive is backed up on a regular basis according to the KSWSC's computer back-up policy.

\section{Borehole Geophysical Logs}

Borehole-geophysical logs are archived following the guidelines established by the OGW Technical Memoranda 2010.01 (U.S. Geological Survey, 2010b) and 2000.03 (U.S. Geological Survey, 2000a). The permanent storage area is the LOGARCHIVE folder in the KSWSC data archive directory. 
The Log Archiver software (available on an internal web site at KSWSC) will be used to facilitate the process of archiving the geophysical logs.

\section{Equus Beds Geodatabase}

An ArcGIS geodatabase has been established to store and archive various information relative to the Equus Beds Aquifer Storage and Recovery project. This geodatabase provides a single place to store and archive important project information. The geodatabase includes data from NWIS including site-file information, well depths and screened intervals, water levels, streamflows, and water-quality data and information. The geodatabase also is a repository for groundwater-level data from the WIZARD database and the city of Wichita. The water-well completion records (WWC5) driller's logs, wateruse data from Water Information Management and Analysis System program (WIMAS), and Groundwater Management District No. 2 and KDHE water-quality data also are included in the Equus Beds geodatabase.

\section{Data Publications and Dissemination}

Disseminating information to Congress and the general public is a requirement of USGS. The USGS KSWSC uses NWISWeb, project Web sites on the internet, and electronic and hard-copy publications to disseminate scientific information to the public. Exceptions to the requirement to publish all data, including data collected under an agreement of confidentiality, will be approved in writing by the KSWSC Director in consultation with OGW. Guidance on release of sensitive water-related information can be found in an Office of Water Information memorandum dated July 17, 2008 (U.S. Geological Survey, 2008a) and available on an internal web site at the KSWSC.

The USGS Fundamental Science Practices (FSP) governs how scientific investigations, research, and activities are planned and conducted, and how information products are reviewed and approved for release and dissemination ( $h t t p: / /$ www.usgs.gov/fsp/policies.asp). The policy and guidelines in FSPs guide how USGS KSWSC disseminates scientific information products.

Approved data for public use are served on NWISweb. Data can be released to the public as "Provisional—Subject to revision" after preliminary review for accuracy by the Project Chief or Data Chief. Discrete and continuous-record groundwater data collected for basic data-collection programs and interpretive and research projects during a water year (for example, the 2013 water year is October 1, 2012 to September 30,2013) are stored in NWIS and are available through NWISWeb. Some groundwater data collected as part of project work may be published in a data report or in the final interpretive report for that project.

Data furnished by sources other than USGS are used for analysis and published if the data have been appropriately quality assured. If the data have not been thoroughly quality assured, the data are described in terms of qualifications and limitations. In either case, the source of the data is acknowledged.

The quality and accuracy of data and interpretive reports are assured by the eight- to nine-step report review process illustrated in table 2 . Release of preliminary interpretations prior to final approval is prohibited to avoid disseminating incomplete and (or) incorrect conclusions, which are subject to change as a result of subsequent technical and policy reviews. There can be more than two colleague reviewers depending on report complexity, generally one USGS reviewer from the KSWSC office and one USGS reviewer from another office. If courtesy reviews are requested from cooperators or others outside the USGS, appropriate guidelines for distribution of USGS information prior to publication must be followed. These guidelines are part of the USGS Fundamental Science Practices (Fundamental Science Practices Advisory Committee, 2011) and Chapter 502 of the U.S. Geological Survey Manual (U.S. Geological Survey, [n.d.]a,b), and are summarized in appendix 4 (Jerad D. Bales, written commun., June 2013). Preparation of a preliminary report outline while preparing the project work plan and periodic management and technical reviews increases the likelihood that reports will be delivered to the customer in a timely manner.

\section{Audits}

Audits are designed to ensure that all tasks described in the GWQAP are being performed. Audits are documented quality-assurance activities performed to determine compliance with the GWQAP and associated documents and the effectiveness of their implementation. Audits include observing field data-collection activities and reviewing office documentation. Audits usually are peer reviews. Audits are performed during the Technical Water Science Center Reviews that occur every 3 years. 
Table 2. Report review process for quality assurance in the U.S. Geological Survey Kansas Water Science Center.

[OMB, Office of Management and Budget; WSC, Water Science Center; SPN, Science publishing network]

\begin{tabular}{|c|c|c|}
\hline Step & Description & Action \\
\hline \multirow[t]{2}{*}{1} & Staff overview & $\begin{array}{l}\text { Checks organization, completeness of content, verification spot checks, ensures that } \\
\text { project objectives are met, and arranges for complete verification review. Report entered } \\
\text { into Information Product Data System }\end{array}$ \\
\hline & Author(s) revisions & Revise and submit to next step. Suggests peer reviewers \\
\hline \multirow[t]{2}{*}{2} & Supervisor review & $\begin{array}{l}\text { Determines if report is ready for peer review; accepts author's suggested reviewers or } \\
\text { identifies other reviewers; monitors whether report could be considered as influential or } \\
\text { highly influential scientific information for the OMB Peer Review Agenda process. }\end{array}$ \\
\hline & $\begin{array}{l}\text { Peer review (one internal and one } \\
\text { external to the USGS Kansas WSC) }\end{array}$ & Checks technical validity of analyses and supporting data, organization, and readability. \\
\hline 3 & $\begin{array}{l}\text { Author revisions and response to } \\
\text { reviewers }\end{array}$ & $\begin{array}{l}\text { Revise, write response, and submit to next step. See USGS Fundamental Science Practices } \\
\text { and Survey Manual sections } 502.1 \text { through } 502.5 \text { (http://www.usgs.gov/fsp/). }\end{array}$ \\
\hline \multirow[t]{3}{*}{4} & Supervisor check & $\begin{array}{l}\text { Determines if response to peer review comments is adequate and if editorial review is } \\
\text { required. }\end{array}$ \\
\hline & Review by Section Chief & $\begin{array}{l}\text { Check adequacy of response to reviewer comments, data analysis, and correctness of } \\
\text { interpretation. }\end{array}$ \\
\hline & SPN preparation & Prepares report for approval by WSC Director. \\
\hline 5 & Review by WSC Director & $\begin{array}{l}\text { Approval for publication (noninterpretive reports) or recommended approval for publica- } \\
\text { tion (interpretive reports). }\end{array}$ \\
\hline 6 & Review by Bureau Approving Official & $\begin{array}{l}\text { Ensures all required reviews are performed, validates peer review reconciliation, identifies } \\
\text { any revisions needed, and returns (for additional review or revision approved or unap- } \\
\text { proved package) to WSC Director (interpretive reports). }\end{array}$ \\
\hline 7 & WSC Director & Sends to author for appropriate action \\
\hline
\end{tabular}

\section{Summary}

This report provides a plan to direct the quality assurance of groundwater activities in the Kansas Water Science Center and presents policies pertaining to training; planning; data collection, processing, review, analysis, and storage; publications; archiving; and audits as they relate to these activities. This report also includes a data management process that describes how the Kansas Water Science Center manages data from field data collection to the end of a project. The implementation of these plans will enhance the consistency, accountability, comparability, traceability, and repeatability of groundwater activities of the Kansas Water Science Center.

\section{Acknowledgments}

The Kansas Water Science Center data management plan was adapted from existing plans in Oklahoma and Colorado Water Science Centers. The methods for calibration of graduated steel and electric tapes for measuring water levels were adapted from the Arkansas Water Science Center. 


\section{Selected References}

Alley, W.M., Reilly, T.E., and Franke, O.L., 1999, Sustainability of ground-water resources: U.S. Geological Survey Circular 1186, 79 p. (Also available at http://pubs.usgs.gov/ circ/circ1186/.)

Brunett, J.O., Barber, N.L., Burns, A.W., Fogelman, R.P., Gillies, D.C., Lidwin, R.A., and Thomas, J.M., 1997, A qualityassurance plan for district groundwater activities of the U.S. Geological Survey: U.S. Geological Survey Open-File Report 97-11, 19 p. (Also available at http://water.usgs.gov/ ogw/pubs/OFR9711/.)

Cunningham, W.L., and Schalk, C.W., comps., 2011 Groundwater technical procedures of the U.S. Geological Survey: U.S. Geological Survey Techniques and Methods, book 1, chap. A1, 151 p. (Also available at http://pubs.er.usgs.gov/ publication/tm 1A1.)

Fundamental Science Practices Advisory Committee, 2011, U.S. Geological Survey Fundamental Science Practices: U.S. Geological Survey Circular 1367, 8 p. (Also available at http://pubs.usgs.gov/circ/1367/.)

Green, J.H., 1991, WRD project and report management guide: U.S. Geological Survey Open-File Report 91-224, 152 p. (Also available at http://pubs.er.usgs.gov/pubs/ofr/ ofr91224.)

Hubbard, E.F., comp., 1992, Policy recommendations for management and retention of hydrologic data of the U.S. Geological Survey: U.S. Geological Survey Open-File Report 92-56, 32 p.

Kansas Department of Health and Environment, 2011, Procedure for plugging a groundwater monitoring well, procedure no. WWP-10, 2 p. http://www.kdheks.gov/waterwell/ download/WWP-10.pdf.)

Lane, S.L., and Fay, R.G., 1997, Safety in field activities: U.S. Geological Survey Techniques of Water-Resources Investigations, book 9, chap. A9, 75 p. (Also available at http://water.usgs.gov/owq/FieldManual/Chap9/content. html.)

Lapham, W.W., Wilde, F.D., and Koterba, M.T., 1995, Ground-water data-collection protocols and procedures for the National Water-Quality Assessment Program: selection, installation, and documentation of wells, and collection of related data: U.S. Geological Survey Open-File Report 95-398, 70 p. (Also available at http://pubs.usgs.gov/ of/1995/ofr-95-398/.)

Lapham, W.W., Wilde, F.D., and Koterba, M.T., 1997, Guidelines and standard procedures for studies of ground-water quality-Selection and installation of wells, and supporting documentation: U.S. Geological Survey Water-Resources Investigations Report 96-4233, 110 p. (Also available at http://water.usgs.gov/owq/pubs/wri/wri964233/.)
Scott, J.C., 1990, Computerized stratified random site selection approaches for design of a ground-water-quality sampling network: U.S. Geological Survey Water-Resources Investigations Report 90-4101, 109 p. (Also available at http://pubs.usgs.gov/wri/1990/4101/report.pdf.)

Seanor, R.C., Schalk, C.W., and Pope, D.A., 2013, User's manual for the National Water Information System of the U.S. Geological Survey-Management and population of sites (MAPS) Program, version 5.1: Reston, Virginia, U.S. Geological Survey, 37 p. (Also available at http://nwis.usgs. gov/nwisdocs5_1/gw/MAPS/MAPS.Documentation.pdf.)

Shampine, W.J., Pope, L.M., and Koterba, M.T., 1992, Integrating quality assurance in project work plans of the U.S. Geological Survey: U.S. Geological Survey Open-File Report 92-162, 12 p. (Also available at http://pubs.er.usgs. gov/pubs/ofr/ofr92162.)

Stallman, R.W., 1976, Aquifer-test design, observation and analysis: U.S. Geological Survey Techniques of WaterResources Investigations, book 3, chap B1, 26 p. (Also available at http://pubs.er.usgs.gov/publication/twri03B1.)

U.S. Geological Survey, [n.d.]a, USGS Fundamental Science Practices: U.S. Geological Survey, [unnumbered pages], accessed May 23, 2013, at http://www.usgs.gov/fsp/default. asp.

U.S. Geological Survey, [n.d.]b, U.S. Geological Survey Manual-Chapter 502: U.S. Geological Survey, [unnumbered pages], accessed July 30, 2013, at http://www.usgs. gov/usgs-manual/t500.html.

U.S. Geological Survey, 2013a, Programs and Plans-Guidelines for preparation, submission, and approval of water science center project proposals: Water Mission Area Policy Memorandum 13.01, accessed January 24, 2014 at http:// water.usgs.gov/admin/memo/policy/wmapolicy13.01.pdf.

U.S. Geological Survey, 2013b, Policy prohibiting the creation of duplicate sites and data in the national water information system: Water Mission Area Policy Memorandum 13.03, accessed January 24, 2014 at http://water.usgs.gov/admin/ memo/policy/wmapolicy13.03.html.

U.S. Geological Survey, 2012a, Policy for release of continuous water-temperature data recorded from secondary sensors at streamgages and wells: Office of Ground-Water Technical Memorandum 2012.02, accessed September 12, 2013 at http://water.usgs.gov/admin/memo/GW/gw12.02. html.

U.S. Geological Survey, 2012b, Update of policy on review and publication of discrete water data: Office of Groundwater Technical Memorandum 2012.03, accessed June 3, 2013, at http://water.usgs.gov/admin/memo/GW/gw12.03.pdf. 
U.S. Geological Survey, 2012c, Policy for evaluation of well integrity for water-level measurements-Initial application to CBR network wells and test phase for all wells: Office of Ground-Water Technical Memorandum 2012.01, accessed May 21, 2013, at http://water.usgs.gov/admin/memo/GW/ gw12.01.html.

U.S. Geological Survey, 2011, Groundwater flow and transport model archival Office of Ground-Water Technical Memo-

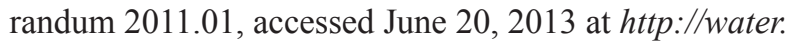
usgs.gov/admin $/ \mathrm{memo} / \mathrm{GW} / \mathrm{gw} 11.01 . \mathrm{html}$.

U.S Geological Survey, 2010a, Continuous records processing of all water time series data: Water resources Discipline Memorandum 2010.02. accessed June 26, 2013 at $h t t p: / /$ water.usgs.gov/admin/memo/policy/wrdpolicy10.02.html.

U.S. Geological Survey, 2010b, Update of the national policy to archive borehole-geophysical logs: Office of Groundwater Technical Memorandum 2010.01, accessed July 26, 2013 at http://water.usgs.gov/admin/memo/GW/gw10.01. html.

U.S. Geological Survey, 2009, Update on guidance for the preparation, approval, and archiving of aquifer-test results: Office of Ground-Water Technical Memorandum 2009.01, accessed May 21, 2013, at http://water.usgs.gov/admin/ memo/GW/gw09.01.html.

U.S. Geological Survey, 2008a, Guidance on release of sensitive water related information: Office of Information memorandum dated July 17, 2008, accessed June 20, 2013 at $h t t p: / / n w i s . u s g s . g o v / c o m m u n i c a t i o n s / 2008 n e w s / 080717 s e$ nsitive_data_guidelines.html.

U.S. Geological Survey, 2008b, Water Resources Discipline policy on accepting furnished record: Water Resources Discipline Memorandum 2008.01, accessed June 20, 2013 at http://water.usgs.gov/admin/memo/policy/wrdpolicy08.01. html.

U.S. Geological Survey, 2006a, Storage of water-level data for ground water: Office of Ground-Water Technical Memorandum 2006.01, accessed June 26, 2013 at http://water.usgs. gov/admin/memo/GW/gw06.01.html.

U.S. Geological Survey, 2006b, Collection, quality assurance, and presentation of precipitation data: Office of Surface Water Technical Memorandum 2006.01, accessed June 3, 2013, at http://water.usgs.gov/admin/memo/SW/sw06.012 Revised_122009.pdf.

U.S. Geological Survey, 2000a, Establishment of a national policy to archive borehole-geophysical logs: Office of Ground-Water Technical Memorandum 2000.03, accessed June 3, 2013, at http://water.usgs.gov/admin/memo/GW/ gw00.03.html.
U.S. Geological Survey, 2000b, Update of the national policy to archive ground water flow and transport models: Office of Ground-Water Technical Memorandum 2000.02, accessed June 3, 2013, at http://water.usgs.gov/admin/ memo/GW/gw00.02.html.

U.S. Geological Survey, 1999, Preservation of original digital field-recorded time-series data: Water Resources Discipline Memorandum 99.33, accessed June 25, 2013 at http://water. usgs.gov/admin/memo/policy/wrdpolicy99.33.html.

U.S. Geological Survey, 1997a, Release of Open-File Report 97-11 "A Quality-Assurance Plan for District GroundWater Activities of the U.S. Geological Survey": Office of Groundwater Technical Memorandum 97.03, accessed June 3, 2013 at http://water.usgs.gov/admin/memo/GW/gw97.03. html.

U.S. Geological Survey, 1997b, Clarification of policy for using non-U.S. Geological Survey computer programs in ground-water projects: Office of Ground-Water Technical Memorandum 97.01, accessed June 3, 2013, at http://water. usgs.gov/admin/memo/GW/gw97.01.html.

U.S. Geological Survey, 1996, Policy on documenting the use of ground-water simulation in project reports: Office of Ground-Water Technical Memorandum 96.04, accessed June 3, 2013, at http://water.usgs.gov/admin/memo/GW/ gw96.04.html.

U.S Geological Survey, 1994, Guidelines for the preparation, approval, and archiving of aquifer-test results: Office of Ground-Water Technical Memorandum 1994.02, accessed June 26, 2013.

U.S. Geological Survey, 1992, Policy for management and retention of hydrologic data of the U.S. Geological Survey: Water Resources Memorandum 92.59, accessed June 24, 2013 at http://water.usgs.gov/admin/memo/policy/ wrdpolicy92.059.html.

U.S. Geological Survey, 1980, National handbook for recommended methods for water-data acquisition, chap. 2Ground water: U.S. Geological Survey Work Group 2

Wagner, R.J., Boulger, R.W., Jr., Oblinger, C.J., and Smith, B.A., 2006, Guidelines and standard procedures for continuous water-quality monitors - Station operation, records computation, and data reporting: U.S. Geological Survey Techniques and Methods, book 1, chap. D3, 96 p. 


\section{Appendixes 1-4}




\section{Appendix 1-Establishment of Site Files for New Groundwater Data- Collection Sites}

The establishment of site files for new groundwater datacollection sites in the Kansas Water Science Center (KSWSC) National Water Information System (NWIS) database is accomplished by a five-step process, which includes the following: (1) conducting a search for duplicate data-collection sites, (2) locating a site, (3) establishment of site ID and site name, (4) Groundwater Site Information (GWSI) site schedules, and (5) creating station folders.

\section{Conducting a Search for Duplicate Data- Collection Sites}

To eliminate the creation of duplicate data-collection sites, project staff should first complete a thorough search of the NWIS database for existing sites located near the proposed site. Ideally, this process will be conducted prior to the physical reconnaissance of the study area and the establishment of any new site. There are two methods to conduct the site search for duplicate sites within a specified radius of any proposed site. Guidance on methods to eliminate duplicate sites is contained in Water Mission Area policy memorandum 2013.03 (U.S. Geological Survey, 2013b). There are limitations to these programs. MAPS will only display sites from the local NWIS host. The NWIS Mapper will display sites without regard to the host but only sites that are pushed to the web, not local sites or proprietary sites. Neither application will indicate sites with nonstandard coordinates coded in the site file; for example, latitude and longitudes other than NAD 27 and NAD 83. Other data cannot be converted for mapping purposes.

- One method is the NWIS program MAPS. Documentation is at http://nwis.usgs.gov/nwisdocs4_10/gw/MAPS/ MAPS.Documentation.pdf.

- A second method is the NWIS mapper at http://maps. waterdata.usgs.gov/mapper. Zoom into the area of interest. Ensure that the correct site types are selected in the left box.

If a site already exists for the proposed site location, that site ideally will be used after updating the existing site-file information in NWIS. To update the site file, locate the sitefile folder - consult the NWIS DBA, Project Chief, or office Data Chief for assistance. Update the existing hard copies of the GWSI site schedules and then update the site file in NWIS.

\section{Locating Site}

All new sites for which GWSI site files will be established must be physically located with a GPS receiver, preferably by the project staff (or designee) — record latitude-longitude to the nearest second using NAD83 datum. Furnished data may be used if it is considered reliable.

- Office data chiefs (or designee) or project staff must develop a detailed site sketch in the field. Site photographs are strongly encouraged. The site sketch and photographs will be permanently stored in the site-file folder.

- Field notes should document the location and physical conditions of the site. Information necessary for the GWSI site schedule will be recorded in the field notes.

- Office Data Chiefs (or designee) or project staff must plot the site location on a 7.5-minute topographic map or digital map. The map will be permanently stored in the site-file folder.

\section{Establishment of Site Identification and Site Name}

\section{Establishing Site Identification}

Groundwater (well, spring)

- Project Chief (or designee) is responsible for establishment of groundwater site IDs. The site ID is composed of a 15-digit site number, which represents the latitude and longitude, and a 2-digit sequence number (for example, 374953097232601). The first site ID assigned to a given 1-minute latitude-longitude grid will have a 2 -digit sequence number of " 01 " and subsequent sites will be ordered sequentially.

\section{Station Naming Convention}

\section{Groundwater}

- Office Data Chiefs (or designee) or project staff must determine station name using only capital letters.

- Station (local) names will require a modification of the Bureau of Land Management's system of land subdivision. The first number indicates the township south (S), the second indicates the range east or west (E or W) of the sixth principal meridian, and the third indicates the section in which the well is located. The first letter following the section number denotes the quarter section or 160-acre tract, the second letter denotes the quarter-quarter section or 40-acre tract, and the third letter denotes the quarter-quarter-quarter section or 10 -acre tract. In some cases, a fourth letter is added, denoting the quarter-quarter-quarter-quarter section or 5 -acre tract. The 160-acre, 40-acre, 10-acre, and 5-acre tracts are designated A, B, C, and D in a counterclockwise direction beginning in the northeast quarter of the 
section. Wells or sampling sites in a tract are numbered consecutively, beginning with 1 , in the order in which the wells or sites were inventoried. For example, stablishment of Site Files for New Groundwater DataCollection Site 01S 03W 04BBD 16 indicates the sixteenth well inventoried in the southeast quarter of the northwest quarter of the northwest quarter of sec. 4, T. 1 S., R 3 W. (fig. 1-1).

- The station (local) name also can include an optional project-specific local name (for example, a well called "810"), which can be appended to the end of the mandatory station name described above. An example of this might be " $25 \mathrm{~S} 01 \mathrm{~W}$ 35DAA 0181 ".

- Station (local) names should not include references to public water supplies, for reasons of national security.

- Station (local) names should not contain any reference to a person's name, living or dead, unless that name is on a USGS topographic map.

\section{Groundwater Site Inventory (GWSI) Site Schedules}

Essential information about the location, identity, data accuracy, and characteristics of a well, surface-water station, or water-quality sampling site are stored in the GWSI site file-all NWIS site files are established through GWSI.

- The GWSI site files will be established prior to collecting any data at a site.

- Prior to entering the site-file information into GWSI, each site must have a completed GWSI coding form (site schedules) (form 9-1904-A, available at KSWSC), either created using the MAPS application or coded manually on paper. Alternately, the Excel-based SWUDS coding templates can be used.

- There are separate GWSI coding forms for wells, springs, and surface-water sites. Required and recommended fields for the well coding forms are listed in GWPD-2 and the "Site Establishment" section of this report.

- After completing the coding, project staff is responsible for checking the forms for completeness and accuracy prior to entering into GWSI.

- In addition to the required fields, the name and date of the person coding the form, checking the data, and entering the data must be entered on the GWSI coding forms.

- The GWSI coding forms, and the GWSI User's manual are available at the KSWSC.

\section{Station Folders}

Project staff is responsible for creating a station folder for any new sites established in NWIS or updating an existing site-file folder if NWIS site files are revised. Old site files (prior to 2014) will be left as hard copy, but new site files will be converted to digital files as the WSC transitions to complete electronic data management.

- The station folders should contain any and all documentation on the physical attributes of any established sites.

- The station folders are to be filed and maintained in the office doing the work; however, site-file folders can be maintained with project files for the life of the project, but upon completion of the project these site files must be moved to the archival directory.

- Information in the station folders can include the items listed below:

- Required access permits from landowner.

- Permits to sample, install wells, gages, or other monitoring equipment (dig safe and building permits).

- Original copy of GWSI coding form 9-1904 or copy of SWUDS file (available at KSWSC).

- Digitally plotted on map with road log information included on map or as separate sheet.

- Safety information, including site safety plan.

- Copy of site information from GWSI, (reviewed, dated, and initialed).

- Original field notes related to the location, establishment, or construction of site.

- Photographs of relevant features of the site. May include surrounding land use.

- Driller's log, geophysical logs, and well-construction information.

- Level notes and computations, including information on the altitude of the land surface and a description of the measuring point, reference points, and benchmarks.

- Hard copy station folders are stored permanently in the KSWSC office that does the work. Digital station folders will be stored in a computer directory. Any original data will be archived appropriately. 


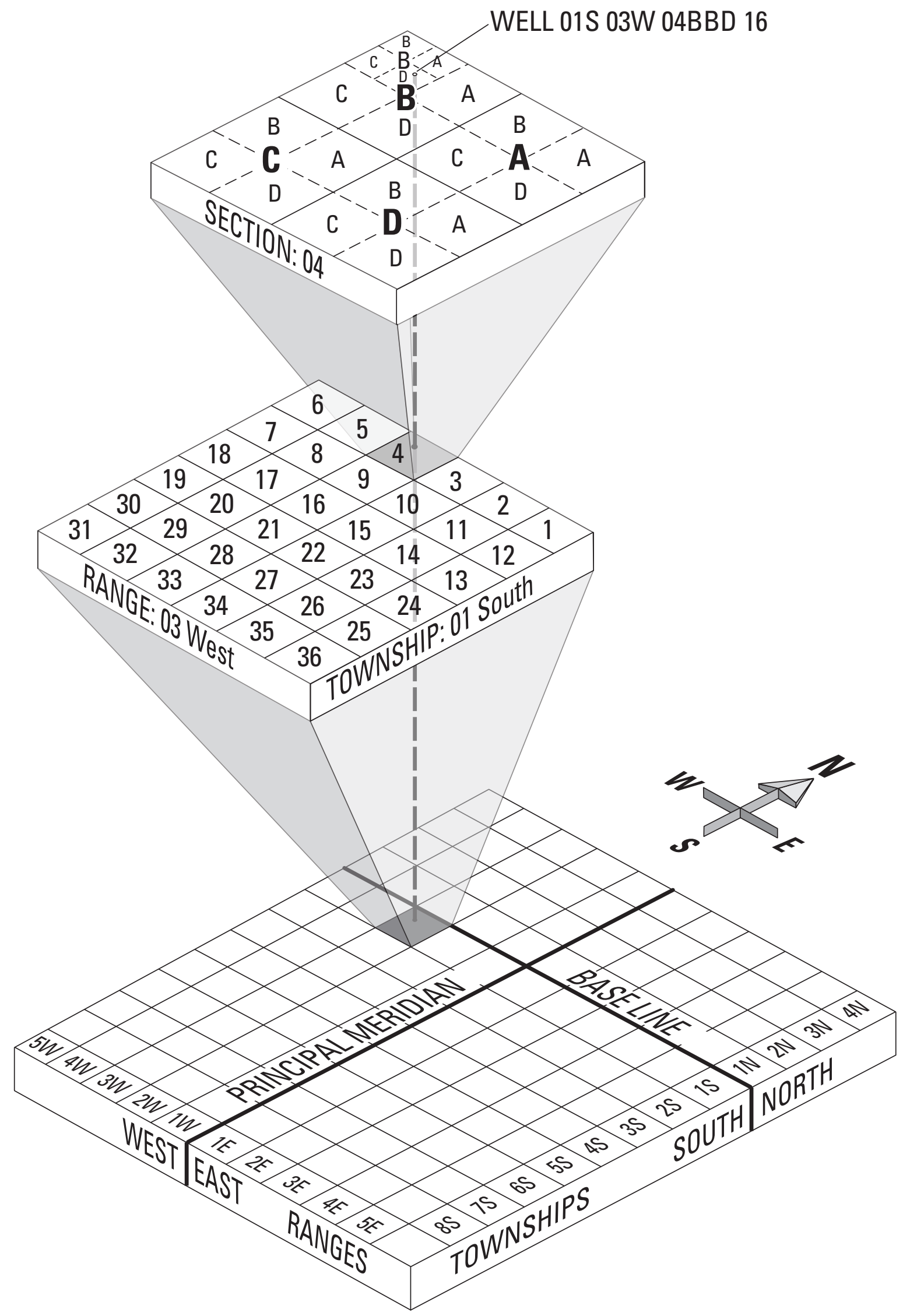

Figure 1-1. Diagram showing modified Bureau of Reclamation system of land subdivision used for identification of wells. 


\section{Appendix 2-Establishment of Real- Time Web Sites}

New sites that will be added to NWISweb need to be properly described and settings must be selected so that data is displayed correctly. New sites that will be displayed on NWISWeb Real-Time Web sites require the following steps to keep them consistent with other sites on the KSWSC Web sites.

\section{Additional Groundwater Site Inventory Requirements for Real-Time Display}

- The site web flag must not be set to P (proprietary) or $\mathrm{L}$ (local). Site Web Flag designations of P or L require approval of the WSC director.

- The site file instrument field (C805) must have a "Y" in field 5 indicating Satellite Telemetry for proper display in SIMS.

\section{Creating the Data Descriptors in ADAPS}

The DBA (or designee) is responsible for creating the Data Descriptors with the following protocol:

Create Data Descriptors (DDs) using SU-greater than 3 greater than 1

- Set only one DD per parameter code to primary “*”. The primary DD will contain all the historical data and will be the DD displayed on the web.

- Most common ADAPS parameter codes are available for web display. The most notable exception is precipitation, which requires parm code 00045 for web display.

- Additional requirements for the display of precipitation data (parm 00045) can be found at http://water.usgs. gov/admin/memo/SW/sw06.012_Revised_122009.pdf (U.S. Geological Survey, 2006b).

- The DCPid entered when creating performance IDs is selected from several national programs. Whenever a new DCPid is used, it will be updated for all performance DDs using the DD edit menu.

Create Processors using (SU->3 ->2)

- Processors should only be created for "output" DDs.

- Processors will be set to approved as they are created.

- Never delete a processor. Changes in processors will be done by creating a new one and leaving the old one in case reprocessing or historical knowledge is needed.
- Take care to create only those Daily Values tables for statistic codes that will be formally worked, checked, and reviewed.

- Specific Conductance (00095), Water Temp (00010) and DO (00300), and turbidity use minimum, maximum, and mean DVs.

- $\mathrm{pH}$ (00400) use minimum, maximum, and median DVs.

- Battery (70969) needs a processor to display on the Web, but those should not be set to create Daily Values. If the site transmits every 4 hours, the abort limit must be increased to 240 for proper hydra display.

Create Thresholds using (PR->1)

- Threshold values generally are entered for all DDs that will be displayed on the web.

- All threshold values with the word "critical" will cause the unit value to be marked as " $\mathrm{X}$ " in ADAPS and be masked from the Web.

- Other noncritical thresholds values will be marked in ADAPS and will be displayed to internal web users only.

- The site requester is responsible for entering the thresholds.

\section{Set Up the Decodes}

Decodes is a program that translates raw data transmitted from groundwater monitoring sites to data that can be read and displayed on the Web. The DBA (or designee) is responsible for creating the decode script using information on the Web site checklist.

\section{Set Up the Web Display}

The DBA or Office Data Chief designee is responsible for entering the site into the NWISWeb dataset using "nw_edit."

- This is a fairly straight forward process, but there are a few conventions to remember. Battery voltage access code will be set to two because there is no need for public access. Setting the "contact email" field will not display the individual's email address on the public web, but it would make it easier for the technician to create an individual Web site group.

- For real-time sites, provisional and approved data are sent to the Web.

- For sites that are not real-time, only approved data are sent to the Web. 
- Precipitation, water temperature [in degrees Fahrenheit $\left.\left({ }^{\circ} \mathrm{F}\right)\right]$, and battery voltage should not be entered in DV display.

- If a National Weather Service flood stage is known at the site, it will be entered into option 8 .

\section{Customizing Kansas Web Sites}

The DBA (or designee) is responsible for customizing the station's individual Web site.

Required information includes the following:

- Cooperator information for display on the home page.

- Link to USGS Water Alert that allows users to set up text or email messages when groundwater level exceeds a user-defined threshold.

- Agency "logos.” (file available from KSWSC).

- Station picture if available.

- DBA then creates/edits the following files.

- The following file controls the links and text on the individual station page on the Web. /usr/local / nwisweb/nwis_host/nwisks/local/site_text/Site_no.txt (file available from KSWSC).

- Two directories include photograph information. The directory /usr/local/nwisweb/picures (available at KSWSC) contains an html file for each site's pictures. This file contains the source code, the name of the file of pictures, and the text for the picture. The

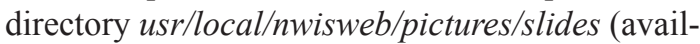
able at KSWSC) contains the actual site pictures.

\section{Add Sensors to Site Visit (optional)}

The DBA or Office Data Chief designee is responsible for adding location sensors using information on the site checklist:

- Use site number for serial number.

- Use site number plus "aux" for nonprimary sensors at the site.

- Add measuring points for crest-stage gages.

\section{Update Administration Files for Continuous Records}

- Contact DBA so the station can be added into the SIMS system, particularly if the site will be published in the ADR .

- Contact the RMS manager (DBA) for the responsible field office so the station can be added to the RMS system after it is added to SIMS. 


\title{
Appendix 3-Groundwater Technical Memorandum 2012.01
}

November 4, 2011

OFFICE OF GROUNDWATER TECHNICAL MEMORANDUM 2012.01

\author{
SUBJECT: Policy for evaluation of well integrity for water-level measurements - initial application to \\ CBR network wells and test phase for all wells
}

\section{Introduction}

Water-level measurements play an important role in tracking the status of a groundwater resource. In order to ensure that a water-level measurement adequately represents the hydraulic head in the groundwater system penetrated by the open interval of the well, it is necessary to assure that the well is in good hydraulic connection with the groundwater system and that this connection has not changed over time. Well integrity should be evaluated routinely for USGS groundwater-level observation wells that are part of a recurring measurement program. Well integrity also should be evaluated for wells measured regularly, but less frequently, such as wells in a synoptic or mass measurement program.

The process of evaluating well integrity differs depending on well construction, well access, frequency of measurement, and other factors. Depending on these factors, well integrity may be evaluated by analyzing water-level measurements, by physical tests, or by a combination of these techniques. The process of evaluating well integrity for water-level measurements described in this memo relies heavily on the use of basic hydrologic principles and proper documentation.

\section{Purpose of this Memorandum}

This memorandum outlines the requirement that all wells funded under the federal Collection of Basic Records (CBR) Program must undergo a routine evaluation of well integrity. In addition, the Office of Groundwater is considering policy options for evaluating well integrity for all USGS groundwater-level observation wells. USGS observation wells include wells measured by USGS personnel and those wells measured by observers. Other organizations that furnish data to the USGS should have similar methods and procedures as the USGS so as to ensure the data that are being published are from wells that are connected to the aquifer in which they are completed. Centers that publish data (including data served on the Internet) from wells measured by other organizations should encourage the agencies furnishing record to adopt the USGS well-integrity procedures or develop their own procedures. Implementation of the policy for CBR wells will allow Water Science Centers, the Water Science Field Team Groundwater Specialists, and the Office of Groundwater to evaluate the requirement for wider implementation for wells not in the CBR program.

\section{Policy for wells in the CBR network}

This policy is presented in terms of office- and field-based procedures. The office-based procedures must be followed for all CBR wells and are recommended for all wells. Implementation of the field-based procedures is more flexible, based on the judgment of the Center Groundwater Specialist.

\section{Office-Based Evaluation of Well Integrity}

\section{Annual Hydrograph Check}

- Check water-level fluctuations in the well over time and look for indications of a change in well performance, such as a change in the response of the well or a noticeable change in the range of responses. This should be done annually for wells with continuous or frequent measurements. These observations should be documented in the paper site folder, station analysis, or other digital documentation for the well, such as the Site Information Management System (SIMS). 


\section{Field-Based Evaluation of Well Integrity}

\section{Each Site Visit}

- Check the physical condition of the well and well installation and document these observations in the site folder. Changes in and around the well may have an effect on well integrity in the short- or long-term.

\section{Annual Total Depth Measurement}

- If access to the well is suitable for a total depth (sounding) measurement, check the depth of the well. If the recorded depth of the well has changed significantly, or the depth indicates that the effective open-screen length has decreased significantly, then well integrity could be compromised and additional testing may be necessary. A method for measuring well depth by use of a graduated steel tape is outlined in USGS Groundwater Procedures Document 11 (Cunningham and Schalk, 2011). The total depth measurement should be documented in the paper site folder, station analysis, or other digital documentation for the well. If access to the well is unsuitable for a total depth measurement, this also should be documented.

\section{Periodic Hydraulic Testing}

- If access to the well is suitable for a hydraulic test, some type of repeatable hydraulic test must be conducted upon site establishment, and as necessary throughout the life of the well. As described above, the field evaluation, annual measurement of total depth, and annual evaluation of the hydrograph will provide a good initial check on well integrity. But a quantitative measure of well performance/integrity is valuable and necessary periodically, whenever the above evaluation methods indicate a possible degradation in well performance. The policy for observation well hydraulic testing is summarized in the steps listed below.

1. Upon establishment of a new well in a measurement program, conduct a baseline hydraulic test (additional detail provided in attachment "Types of Hydraulic Tests for Well Integrity"). Document the results in the site folder or digital documentation for the well. Future tests will be compared to these baseline test results. If a baseline test was not done when the site was established, it should be done as soon as possible.

2. Conduct the annual hydrograph check, the site visit check for well physical condition, and the annual measurement of total depth as described above.

3. If the evaluation in step number 2 suggests a degradation of well integrity, repeat the hydraulic test. If the waterlevel response from the repeat hydraulic test differs significantly from previous tests, the well should be examined more thoroughly (perhaps by using geophysical techniques) and a decision made whether to rehabilitate the well (such as by redeveloping) or to properly abandon the well.

4. The evaluations described in step number 2 above may not always detect degraded well integrity. Thus a hydraulic test should be repeated as time and resources permit, and re-testing is recommended every 3-5 years for all wells in critical networks or used in critical management decisions. The term "critical" is subjective but should include monitoring wells that a cooperator or the public uses to evaluate the effects of nearby groundwater depletions, climate change, or groundwater/surface-water interaction.

5. Each step of the well integrity evaluation must be documented in the paper site folder, station analysis, or other digital documentation for the well

\section{Evaluation for wells not in the CBR network}

The above policy will immediately apply to CBR network wells and its application will be evaluated for wells not in the CBR network based on input from Water Science Center and WSFT Groundwater Specialists. The Centers are encouraged to apply the policy to all wells, regardless of whether they are in the CBR network, in order to appropriately evaluate the policy. There 
are some special cases where implementation of the policy is not feasible or burdensome and the Office of Groundwater would like to identify these cases in order to determine appropriate approaches for evaluating well integrity. One such case is for wells measured infrequently (less than once per year or part of synoptic measurements).

\section{Prospective Evaluation Approach for Wells Measured Less Frequently Than Once per Year}

Some network wells are measured infrequently, but are in a regular measurement program. This is common for wells that are part of a synoptic or mass measurement program. Potentiometric surface maps commonly are produced from these measurements. Even though these wells are measured infrequently, it is important that their integrity be evaluated. Each measurement should be evaluated by comparing it to past measurements. If a measurement is outside the range of expected measurements, as suggested from past measurements, it should be re-evaluated. If potentiometric surface maps are made from the water-level measurements, any measurement that seems to deviate from the conceptual model of the groundwater-flow system should be re-evaluated. Best hydrologic judgment should be used to determine the accuracy of the measurement and the extent to which the measured value is representative of the aquifer hydraulic head. If measurements are judged to be anomalous, field-related well integrity checks may be needed to determine the integrity of the well; methods such as total well depth measurement (and comparison to previous depth measurements), well-integrity hydraulic tests, borehole geophysical logs, and borehole camera surveys can be used for this purpose.

\section{Water Science Center Performance Evaluation}

The Water Science Field Team Groundwater Specialists and the Office of Groundwater representatives will review the wellintegrity documentation during the triennial Water Science Center Technical Reviews. In addition, the Water Science Field Team Groundwater Specialists and the Office of Groundwater encourages Water Science Center personnel to develop effective screening tools to evaluate well integrity for wells with continuous measurements and to share these with the groundwater community.

\section{References cited}

Cunningham, W.L., and Schalk, C.W., comps., 2011, GWPD 11-Measuring well depth by use of a graduated steel tape (Version: 2010.1): in Groundwater technical procedures of the U.S. Geological Survey (Cunningham, W. L., and Schalk, C.W., comps.): U.S. Geological Survey Techniques and Methods 1-A1, 151 p. at http://pubs.usgs.gov/tm/1al/.

Cunningham, W.L., and Schalk, C.W., comps., 2011, GWPD 17-Conducting an instantaneous change in head (Slug) test with a mechanical slug and a submersible pressure transducer (Version: 2010.1): in Groundwater technical procedures of the U.S. Geological Survey (Cunningham, W. L., and Schalk, C.W., comps.): U.S. Geological Survey Techniques and Methods 1-A1, 151 p. at http://pubs.usgs.gov/tm/1a1/.

William M. Alley /s/

Chief, Office of Groundwater

Distribution (bcc): GS-W WSC Directors, GS-W CD, GS-W A, GS-W GW All, OGW

ATTACHMENT: Types of Hydraulic Tests for Well Integrity

\section{ATTACHMENT}

\section{Types of Hydraulic Tests for Well Integrity}

A change in hydraulic test results over time is an indicator of a change in well integrity. The approach used for a hydraulic test is to induce a change in water level in the well and measure the water level as it returns to equilibrium. This test can be done in many ways, and some flexibility is necessary based on well construction, well accessibility, and instrument configuration, for example. 
A single-well "slug test" using a mechanical slug or air (pneumatic test) is recommended for wells in a regular measurement program such as the Collection of Basic Records (CBR) Program. If a single-well test using a mechanical slug or air is not possible, another repeatable approach to induce water-level change in the well must be used. This can be done using a pump, bailer, or by pouring clean water into the well. Method repeatability over time is a key aspect to the choice of method. All future tests should be run identically to the baseline test in order to simplify the comparison of results. The text below provides basic guidance on several types of tests. Details for each type are available in the literature (for example, Butler, 1998).

\section{Mechanical slug}

USGS field procedures for conducting a mechanical slug test are provided in Groundwater Technical Procedure 17 (Cunningham and Schalk, 2011).

\section{Pneumatic slug}

A pneumatic slug test differs from a mechanical slug test in that the initiation of the change in water level is accomplished with air pressure. This test requires the ability to seal the top of the well and pressurize the well, which lowers the water level; then, the sudden release of the pressure results in the rise of water level. Such tests are always conducted using a pressure transducer, data logger, and field computer. If pressurization is instantaneous, both a falling-head and rising-head test can be conducted. Most of the time, however, well pressurization is not instantaneous and only the rising-head part of the test can be evaluated.

\section{Poured slug}

A poured slug test initiates the water-level change by pouring a known volume of water into the well. Use of deionized water is preferable. However, if an observation well is being tested, and no water-quality samples are collected, use of tap water may be acceptable. Because this test creates a sudden rise in the water level, only a falling head test can be conducted. An electric tape, steel tape, or pressure transducer and data logger can be used to record the water level as the water level returns to the pre-test (static) conditions.

\section{Bailing the well}

A bailer test initiates the water-level change by suddenly removing a known volume of water from the well using a bailer. The bailer is lowered into the well and allowed to fill with water; rapid removal of the filled bailer creates a sudden drop in water level. The subsequent water-level rise, and return to the static water level, is measured over time. Thus, only a rising head test can be conducted. An electric tape, steel tape, or pressure transducer and data logger can be used to record the water level as the water level returns to the pre-test (static) water level.

\section{Pumping the well}

Well tests that involve the pumping of a well (for example, a specific capacity test) are usually not required because of the additional time and equipment required. The USGS measures many irrigation, production, and public water supply wells. Some of these wells have dedicated pumps and some do not. Wells that are pumped regularly, probably are in good connection with the aquifer and do not have to be tested unless there is some indication of decreasing connection. The Water Science Centers, however, may want to take advantage of wells that have a pump installed but are not regularly pumped. These might be back up wells in a public water supply well field, or back up irrigation wells that are used only when surface water is not available. Slug tests may not be effective for wells like this, so using the dedicated pump to determine spe- 
cific capacity might be the Water Science Center's most feasible option to check well integrity. A baseline specific capacity test (run by the USGS or reported from the original well installation) would be helpful in cases of suspected anomalous water-level measurements.

\section{$\underline{\text { Key points for all methods }}$}

The purpose of the hydraulic test for well integrity is to determine if the response of the well has changed over time. The goal is not to calculate aquifer properties, although it might be a useful additional step. Regardless of the method used to induce waterlevel change, the following points are relevant for a well-integrity test:

- Document the volume of the slug and calculate the maximum water-level change in the site folder or digital documentation for the well. You should attempt to match this water-level change during any future tests. If the hydraulic test approach is the same among tests, a change in well integrity can be evaluated directly based on the change in water-level recovery time.

- The initial rising or falling head test may be terminated when (a) the water level is equal to the initial water level, or (b) readings change less than $0.01 \mathrm{ft}$ per 10 minutes, or (c) thirty minutes have elapsed.

- If a mechanical slug-test is performed, a second test can be conducted upon removal of the slug if the water level has returned to the initial water level within 30 minutes.

- Document the time it took the water levels to return to the initial water level for all tests. If the water levels in the well did not return to initial levels within 30 minutes, document the percent recovery that occurred in 30 minutes.

- With some additional parameters, an analysis of hydraulic conductivity is possible using all of these methods. However, analysis for hydraulic conductivity is not required by this policy.

In summary, the main objective of a well-integrity test is to evaluate the hydraulic connection between the well and the aquifer.

The Water Science Center staff has flexibility to determine the best method to accomplish this objective. An important aspect is reproducibility, so that, future tests can be compared to tests already conducted and documented.

\section{References cited}

Butler, J.J., Jr., 1998, The design, performance, and analysis of slug tests: Lewis Publishers, Boca Raton, FL, 252 p.

Cunningham, W.L., and Schalk, C.W., comps., 2011, GWPD 17-Conducting an instantaneous change in head (Slug) test with a mechanical slug and a submersible pressure transducer (Version: 2010.1): in Groundwater technical procedures of the U.S. Geological Survey (Cunningham, W. L., and Schalk, C.W., comps.): U.S. Geological Survey Techniques and Methods 1-A1, 151 p. at http://pubs.usgs.gov/tm/lal/. 


\title{
Appendix 4-Distribution of USGS Information Prior to Publication
}

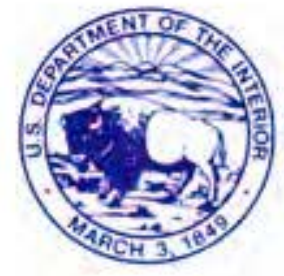

\section{United States Department of the Interior}

\author{
U.S. GEOLOGICAI SURVEY \\ Reston Virginia 20192
}

In Reply Refer To:

Mail Stop 409

\section{WATER MISSION AREA MEMORANDUM NO. 13.XX}

June XX, 2013

\section{Subject: Distribution of USGS Information Prior to Publication}

New guidelines are provided by the Water Mission Area (WMA) to Water Science Centers (WSCs) to safeguard unpublished USGS data, information, and associated scientific materials.

The guidelines are consistent with USGS Fundamental Science Practices (FSP) practices, including an important new USGS policy, Fundamental Science Practices: Safeguarding Unpublished U.S.

Geological Survey Data, Information, and Associated Scientific Materials (SM 502.5), which became effective on December 19, 2012.

SM 502.5 speaks plainly to requirements surrounding release of unpublished inform ation for peer and (or) courtesy review prior to the completion of a project and an approved and final USGS publication. Specifically, scientific peer or courtesy review of USGS data or USGS information products is bound by the Bureau's nondisclosure policy to uphold the strictest scientific ethics in ensuring confidentiality of the science that is being reviewed and not disclose or divulge any results or conclusions or make any public statements regarding the science before it is approved, published, and released.

The chapter also speaks plainly to the issue of what is protected from the Freedom of Information Act (FOIA), Specifically, the policy states that scientific peer and (or) courtesy reviews and drafts of any documents used in the decision-making chain, prepared prior to the adoption of a final product or agency position, are considered deliberative and predecisional and are exempt from release through the FOIA process. In the event that such USGS materials are requested through FOIA, WSCs must contact the WMA National FOIA Liaison.

The WMA remains committed to meeting the needs of its funding partners while upholding the Bureau's scientific reputation and underscoring its mandate to provide reliable science to address pressing societal issues across the Nation.

Jerad D. Bales //s// Jerad D. Bales

Acting: Associate Director for Water

Attachment

Distribution: A, B, WSCs 


\section{Safeguarding Unpublished USGS Information}

New guidelines are provided by the Water Mission Area (WMA) to safeguard unpublished USGS data, information, and associated scientific materials.

The guidelines are consistent with USGS Fundamental Science Practices (FSP) practices, including an important new USGS policy, Fundamental Science Practices: Safeguarding Unpublished U.S. Geological Survey Data, Information, and Associated Scientific Materials (M 502.5), which became effective on December 19, 2012.

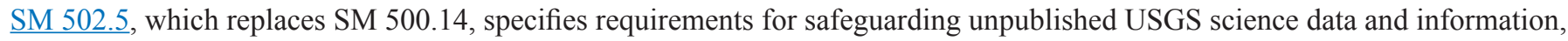
including unpublished deliberative and predecisional information, proprietary data and information, nonproprietary USGS data and information, and associated scientific materials (for example, physical samples).

The chapter speaks plainly to requirements surrounding release of unpublished information for peer and (or) courtesy review prior to completion of a project and an approved and final USGS publication. Specifically, scientific peer or courtesy reviewers of USGS data and USGS information products are bound by the Bureau's nondisclosure policy to uphold the strictest scientific ethics in ensuring confidentiality of the science that is being reviewed and to not disclose or divulge any results or conclusions or make any public statements regarding the science before it is approved, published, and released.

The chapter also speaks plainly to the issue of what is protected from the Freedom of Information Act (FOIA). Specifically, the FOIA process allows a deliberative privilege exemption for communication documents (described on page 5) that Federal agencies develop as part of their decision-making and peer review process. Drafts of documents used in the decision-making chain and prepared prior to the adoption of a final agency position are protected from disclosure. USGS data and information that have not undergone appropriate review and approval are thereby considered documents that are deliberative and predecisional and are exempt from release through the FOIA process.

On the basis of USGS FSPs, this Water Mission Area policy requires Water Science Centers (WSCs) to adhere to the following four (4) guidelines related to the release of pre-published information to Cooperators and (or) outside organizations that are in partnership with the USGS. More detailed information supporting these guidelines is provided below, beginning on page 4 .

\section{Guidelines:}

- Boilerplate statement to be included in cover letter associated with USGS agreements - The following statement is required at the onset of a jointly-planned activity and collaborative partnership in a cover letter accompanying USGS agreements with a Cooperating agency and (or) organizations that are in partnership with the USGS - including a Joint Funding Agreement (JFA), Collaborative Agreement, Cooperative Research and Development aAreement, and (or) a Technical Assistance agreement.

Please note that it is understood that the recipient and signature for an agreement may not be the same as the recipient for pre-published information during the course of a project; however, this guideline establishes the requirement and understanding during the early stages of an agreement and partnership with the Cooperating agency and partnering organization.

During the course of this jointly planned activity and partnership, USGS may disclose unpublished USGS data or information for scientific peer and (or) courtesy review. USGS non-disclosure policy requires recipients of unpublished USGS products not to disclose or release any results or conclusions (in any form), or make any public statements regarding the science before it has been approved and released by the USGS. This confidentiality is critical to uphold the USGS scientific ethical standards for objective, accurate and relevant science. The pre-publication information and reviews are considered deliberative and pre-decisional and are exempt from release through the Freedom of Information Act (FOIA) process. This non-disclosure policy arises from the USGS Fundamental Science Practices (FSP), which underlie USGS science activities, uphold the USGS's scientific reputation, and underscore its mandate to provide reliable science to address pressing societal issues. 
- Boilerplate statement to be included in a cover letter associated with the transmission of pre-published USGS information for peer and (or) courtesy review - The following statement is required in a cover letter accompanying the transmission of pre-published USGS information.

Unpublished data or information is attached for peer and (or) courtesy review by [name of Cooperating agency or partnering organization]. In accepting the unpublished data or information, your agency agrees to be bound by the USGS non-disclosure policy for unpublished USGS work products. Please ensure that these materials are held in strict confidence while under review and prior to publication. Please do not disclose or release any results or conclusions (in any form), or make any public statements regarding the science before it has been approved and released by the USGS. The pre-publication information and reviews are considered deliberative and pre-decisional and are exempt from release through the Freedom of Information Act (FOIA) process. This non-disclosure policy arises from the USGS Fundamental Science Practices (FSP), which underlie USGS science activities, uphold the USGS's scientific reputation, and underscore its mandate to provide reliable science to address pressing societal issues.

\section{- Imbedded statements on USGS pre-publication information:}

- A watermark is required on every page of materials associated with any USGS pre-published data or information, stating "Provisional - Not for Distribution"

Releases that are digital must be converted to a .pdf with a watermark, as defined above.

- The following statement is required as a footnote on pre-published materials, including manuscripts and presentations. Draft material is not for release of circulation. The material has not been peer reviewed or approved for publications by the U.S. Geological Survey (USGS). Content is deliberative and predecisional and does not represent any official USGS findings or policy.

- Actions required in the event of a FOIA request for pre-published materials:

- In the event that deliberative and predecisional USGS materials, such as those prepared during peer and colleague review, are requested through FOIA, WSCs must contact the WMA National FOIA Liaison, which will contact the Department of Interior Solicitor's Office, as instructed in the DOI Departmental manual (FOIA Handbook 383 DM 15).

\section{Supporting Information:}

USGS Fundamental Science Practices (FSP) underlie USGS science activities, uphold the Bureau's scientific reputation, and underscore its mandate to provide reliable science to address pressing societal issues (SM 502.1). The Bureau's rigorous qualityassurance procedures embodied in the USGS FSP ensure that the results of USGS science activities have undergone an appropriate level of scrutiny and review, including peer review and Bureau approval. This process ensures that unbiased, reliable USGS data and information are released ( $\underline{\text { SM 502.4) }}$.

An important new USGS policy, Fundamental Science Practices: Safeguarding Unpublished U.S. Geological Survey Data, Information, and Associated Scientific Materials (SM 502.5), became effective on December 19, 2012. SM 502.5, which replaces SM 500.14, specifies requirements for safeguarding unpublished USGS science data and information, including unpublished deliberative and predecisional information, proprietary data and information, nonproprietary USGS data and information, and associated scientific materials (for example, physical samples). The term "unpublished" in this chapter refers to draft, interim, or background information and materials developed or collected and used to finalize USGS information products for approval and release.

Unpublished data and information gathered through investigations and observations by USGS employees, contractors, and volunteers must not be disclosed until the information is made available to all, impartially and simultaneously, through Bureauapproved publication or other approved means of public release. 
The phrase "not be disclosed until the information is made available to all" as used in this policy does not include disclosure to Federal, State, tribal, local, and governmental agencies and nongovernmental or academic organizations under certain circumstances. Unpublished data and information collected by the USGS can be made available to these agencies for peer and (or) courtesy review for example, under joint funding agreements or other collaborative arrangements or to an individual or group for the purpose of peer review or courtesy review. Reviews of pre-published data and findings and draft manuscripts are intended to ensure the accuracy of data, the scientific validity of interpretations, and the consideration of alternative interpretations.

When the results of an investigation are made available to such an agency, organization, or party, the recipient accepting the unpublished data or information is bound by the Bureau's nondisclosure policy and must not further disclose or release the information in any form or make any public statements regarding the science before it has been approved and released by the USGS (refer to SM 502.3 and SM 502.4 for nondisclosure disclaimer statements). Note that particularly sensitive results, however, such as energy and mineral resource assessments and mineral commodity reports that typically have significant economic implications are not disclosed or shared in advance of public release because pre-release in these cases could result in unfair advantage or the perception of unfair advantage.

Release of pre-published information and peer and courtesy reviews are considered deliberative and predecisional (SM 502.5). The rigorous USGS quality-assurance process (including reviews) embodied in USGS Fundamental Science Practices is deliberative because of the iterative exchange of ideas and opinions among the involved parties. Reviews are considered predecisional because they represent the collective thoughts that are being analyzed to arrive at a final product.

Release of deliberative and predecisional materials could compromise the USGS mission of providing unbiased, objective scientific information upon which other entities may base judgments and could cause the public harm if incorrect or out-of-context information were used for public policymaking or resource management.

The Freedom of Information Act (FOIA) process allows a deliberative privilege exemption for deliberative and predecisional materials that Federal agencies develop as part of their decision-making and peer review process. Drafts of documents used in the decision-making chain and prepared prior to the adoption of a final agency position are thereby protected from disclosure. USGS data and information that have not undergone appropriate review and approval are considered documents that are deliberative and predecisional and therefore are exempt from release through the FOIA process.

USGS materials that are considered deliberative and predecisional and that must not be disclosed or released, even after the resulting information products have been approved and disseminated, include

- original and revised manuscript drafts;

- related documents, working papers, and other information gathered through investigations and observations;

- any required justifications and permissions;

- peer reviewer comments;

- courtesy reviews comments;

- editing comments;

- authors' reconciliation of comments;

- related background materials or history records;

- personally identifiable information (including attributable reviewer comments); and,

- materials, documents, and communications exchanged during the preparation and development of USGS information products intended for publication.

In the event that deliberative and predecisional USGS materials, such as those prepared during peer and colleague review, are requested through FOIA, WSCs must contact the USGS National FOIA Liaison, who will contact the Department of Interior Solicitor's Office, as instructed in the DOI Departmental manual (FOIA Handbook 383 DM 15). 
Publishing support provided by:

Rolla Publishing Service Center

For additional information concerning this publication, contact: Director, USGS Kansas Water Science Center

4821 Quail Crest Place

Lawrence, KS 66049

(785) 842-9909

Or visit the Kansas Water Science Center Web site at: http://ks.water.usgs.gov 

